\title{
A late medieval or early modern light gun barrel from the Castle Museum in Malbork-typology, technology of manufacture and identification of the smelting process
}

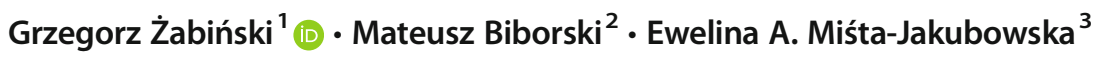

Received: 9 February 2018 / Accepted: 3 May 2018 / Published online: 18 May 2018

(C) The Author(s) 2018

\begin{abstract}
The paper discusses a gun barrel of a possibly late 15th-early 16th c. date from the collection of the Castle Museum in Malbork (Marienburg), Poland (MZM/468/MT). The barrel was originally part of a hand-held gun (a hackbut?) and was later converted into a light cannon. The barrel was made from unevenly carburised soft steel (c. $0.1-0.2 \%$ C). Both metallographic examinations and the analysis of slag inclusions with the use of multivariate statistics suggest that the metal in the barrel was manufactured using the direct (bloomery) smelting process.
\end{abstract}

Keywords 15th-16th c. · Military · Light artillery · Hand-held firearms · Hackbut - Castle Museum in Malbork · Archaeometallurgy $\cdot$ Archaeometry $\cdot$ Slag inclusion analysis $\cdot$ Multivariate statistics

\section{Introduction}

The aim of this paper is to discuss an iron light cannon barrel from the collection of the Castle Museum in Malbork (Marienburg), Poland (inv. No. MZM/468/MT). The exact provenance of the artefact is not known. According to the Museum's inventory card, the barrel was purchased by the Museum from the "DESA" antique shop in Gdańsk (Danzig), Poland in 1982 (Castle Museum in Malbork, Arms and Armour Collection - Cannon Barrel, MZM/468/ MT (inventory card)). Apart from dealing with the typology and chronology of the artefact, a special stress is put on its manufacturing technology and identification of the smelting process in which the metal for the gun barrel was obtained. This issue seems to of particular significance, as the number of firearms (both hand-held and artillery) which underwent technological examinations is still far from satisfactory.

Grzegorz Żabiński

g.zabinski@gmail.com

1 Institute of History, Jan Długosz University, Częstochowa, Poland

2 Laboratory for Archaeometallurgy and Conservation, Institute of Archaeology, Jagiellonian University in Kraków, Kraków, Poland

3 National Centre for Nuclear Research, Świerk, Otwock, Poland
It is generally assumed that iron barrels of hand-held firearms were made by forge-welding one or several iron pieces on an iron core. The barrel was then stopped in the rear (breech) part with a cylindrical peg. Hooks, if present, were then separately forgewelded to the front part of the barrel (on these issues, see, e.g. Strzyż 2014a: p. 232, 234-239; id. 2011: p. 20, 24; Klimek et al. 2013: p. 94-96; Buchwald 2008: p. 285-288; Smith and DeVries 2005: p. 238-239; Szymczak 2004: p. 81, 100; Smith 2000: p. 68-80; Thierbach 1897-1899: 132).

Although technological examinations of hand-held gun barrels were sometimes carried out, attempts at identifying the technology of iron smelting in which the metal was obtained were rather sporadic. An example is a hackbut of a possibly late 15 th or early 16th $\mathrm{c}$. origin from the Castle Museum in Malbork (inv. No. MZM/421/MT). Using the method proposed by Dillmann and L'Héritier (2007), it was found out that the gun was in all probability made from soft bloomery metal (Żabiński et al. 2018).

In most cases, however, only general remarks were made concerning the chemical composition of metal and forging technology. A 14th/15th c. Bohemian handgonne from Ostrožská Nova Vés in Bohemia was manufactured from iron containing $99.92 \% \mathrm{Fe}, 0.05 \% \mathrm{Mn}, 0.08 \% \mathrm{P}$ and $0.05 \% \mathrm{C}$. The barrel may have been forged in a temperature of about $720^{\circ} \mathrm{C}$ and then was slowly cooled down (Figel' et al. 2010: p. 484-485; Strzyż 2014a: p. 236, cat. No. 20). Ferritic iron with a hardness of 
$184 \pm 14$ HV0.01 was used for the manufacture of a hackbut (?) barrel found near Krridlo Castle in Bohemia and dated to perhaps c. 1470 s. The metal was relatively slag-free (Figel' et al. 2010: p. 483; Strzyż 2014a: p. 236-237, cat. No. 76).

High-phosphorus iron was used in a hackbut (turn of the 15th/16th c.) from Helfštýn Castle in Bohemia. Two zones were discovered in the metal: a ferritic one, with c. $0.5-$ $0.6 \% \mathrm{P}$ and a hardness of $161 \pm 14 \mathrm{HV} 0.2$, and a ferriticpearlitic one, which contained $0.2-0.3 \% \mathrm{C}$. The barrel was burst, which was perhaps partially caused by a rather high content of phosphorus and a too high temperature of forging (above $950{ }^{\circ} \mathrm{C}$ ). The latter caused a diffusion of phosphorus into ferritite, which produced micro-cracks in the course of cooling (Figel' et al. 2010: p. 481-484, Fig. 9, p. 486-487, Figs. 10 and 11; Strzyż 2014a: p. 237, cat. No. 75). Ferriticpearlitic alloy containing c. $0.2-0.3 \% \mathrm{C}$ with an average hardness of c. $167 \mathrm{HV} 1$ was also found in a hackbut from Esztergom Castle in Hungary, which is of a similar date (Strzyż 2014a: p. 238, cat. No. 146).

For the sake of comparison, some remarks can also be made concerning the technology of iron-forged artillery. The powder chamber of the stave-and-hoop bombard from Boxted in England (of a possibly 15th c. date) was made from ferriticpearlitic metal containing $<0.04<0.1 \% \mathrm{C}$ and up to $0.36 \% \mathrm{P}$. Its hardness was between 171 and $306 \mathrm{HV} 0.1$. The barrel was also chiefly composed of low-carbon ferrous alloy, with a zone containing up to $0.6 \% \mathrm{C}$. Widmannstätten structures were perhaps related to the process of rapid cooling (Smith and Brown 1989: p. 52-62, Appendix 2, p. 90-93, Tab. 4, p. 94-95, Figs. 78-80, p. 97; see also Smith 2000: p. 75 and Strzyż 2014a: p. 233-234). The stave-and-hoop Mons Meg bombard (1449) was manufactured from wrought iron with between $<0.1$ and $0.5 \% \mathrm{C}$ in the powder chamber. Its hardness was 98-141 HV0.1. The barrel was made from the metal with a higher carbon content $(0.3-0.8 \% \mathrm{C})$, which was also considerably harder (max. 232 HV0.1) (Smith and Brown 1989: p. 1-22, Appendix 2, p. 90-93, Tab. 4, p. 94, Figs. 76-77, p. 96; Smith 2000: p. 75-76).

A higher carbon content was also the case with the heavy stave-and-hoop Dulle Griet from Ghent of a possibly mid15 th c. chronology. The metal contained between 0.05 and $0.7 \% \mathrm{C}$ and such material may have been selected intentionally. Hard steel was perhaps aimed at protecting the barrel against wear related to the use of stone cannonballs (Smith and Brown 1989: p. 23-38, 50, Appendix 2, p. 90-93, Tab. 4, p. 94-95, Figs. 75 and 81, p. 96-97; see also Strzyż 2014a: p. 234). Another stave-and-hoop bombard from Basel in Switzerland (dated to c. 1420s) was manufactured from soft iron containing about $<0.04-<0.1 \% \mathrm{C}$, with an increased phosphorus content. The hardness of the metal varied from 128 and 208 HV0.1 (Smith and Brown 1989: p. 39-45, Appendix 2, p. 90-93, Tab. 4, p. 95, Figs. 82-83, p. 96; see also Strzyż 2014a: p. 234).
Two veuglaire powder chambers stored in the collection of the Regional Museum in Biecz in Poland and dated to about 1450-1525 were also made from soft metal. The first artefact demonstrated ferritic-pearlitic microstructures (c. $0.1-0.2 \%$ C) with an increased content of $\mathrm{P}$ and the hardness of 141 HV1. On the basis of the presence of numerous slag inclusions, it was tentatively proposed that bloomery metal may have been used. The other powder chamber was made from ferritic metal $(0.022 \% \mathrm{C})$ also with an increased $\mathrm{P}$ content. The metal hardness was $172 \mathrm{HV}$ on average (Klimek et al. 2013: p. 85-93, Figs. 5-16; Strzyż 2014a: p. 234-235, cat. Nos. 103-104). Yet, another stave-and-hoop light stone cannonball cannon of a possibly mid-15th chronology was manufactured from wrought iron which contained numerous slag inclusions. It was found out that the internal side of the barrel was more carburised $(0.16 \% \mathrm{C})$ than the external one $(0.01 \% \mathrm{C})$. However, it was assumed that these differences were rather not a result of an intentional process (Schedelmann 1939: p. 81-82, Fig. 2).

A special case is offered by a cannon from the Museum of Artillery in Woolwich in England (perhaps mid-15th c.). Slag inclusions (often globular in shape) sometimes contained very little iron $(3.60,3.00$ and $17.80 \% \mathrm{Fe})$. The amount of Mn was high $(12.90,13.60$ and $9.20 \%)$, as opposed to max. $5.30 \%$ in other examined cannons. The content of carbon was $<0.1-$ $0.2 \% \mathrm{C}$ both in the powder chamber and in the barrel, while the hardness was between 117 and 143 HV0.1. It has been assumed that the metal may have been obtained in the indirect (blast furnace) process (Smith and Brown 1989: p. 84-87, Appendix 2, p. 90-93, Tab. 4, p. 94, Figs. 73-73, p. 96, Appendix 3, Table 6, p. 101, 102; see also Smith 2000: p. 76 and Strzyż 2014a: p. 234; for cast iron cannons see Williams 2012: p. 194, 197 and Buchwald 2008: p. 275, 323-330, 412-413, 426-427; see also Johanssen 1918: p. 1-20).

\section{Description and metrical data}

The barrel is octagonal in cross-section almost throughout its entire length, save the muzzle part. It slightly narrows toward the muzzle (Fig. 1). The state of preservation of the artefact is reasonable, with some corrosion pits on the surface. In the front part, there is an iron ring. This ring was perhaps supposed to reinforce the barrel and may be a later addition. This is also implied by the fact that the barrel's cross-section between the ring and the muzzle is round (Fig. 2a). The latter trait suggests that the muzzle part was re-forged. At c. 1/3 length of the barrel, there are two trunnions which are reinforced with an iron ring and what seems to be a wedge on the bottom side of the barrel. These parts of the barrel can be later additions, too. At a distance of c. $14 \mathrm{~cm}$ from the trunnions toward the breech, a c. 0.5 -cm-wide groove can be seen on 
Fig. 1 Gun barrel, Castle Museum in Malbork (MZM/468/ MT) - general view from above and below (top) and a 3D reconstruction with a crosssection (bottom)
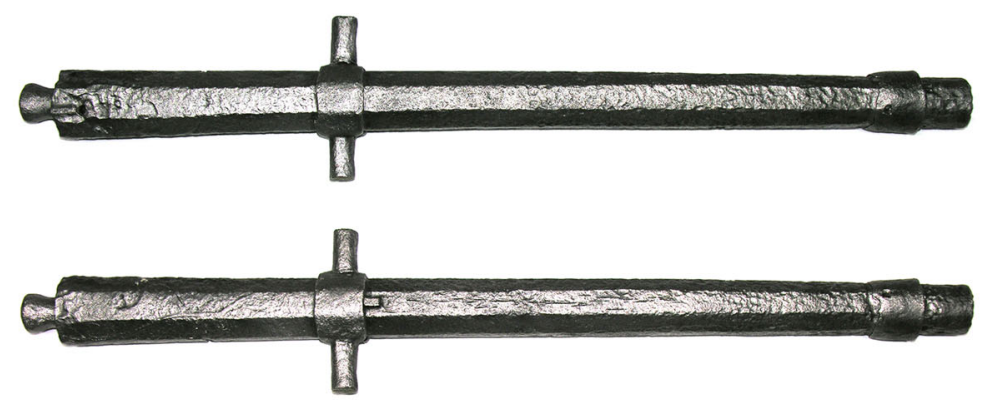

0
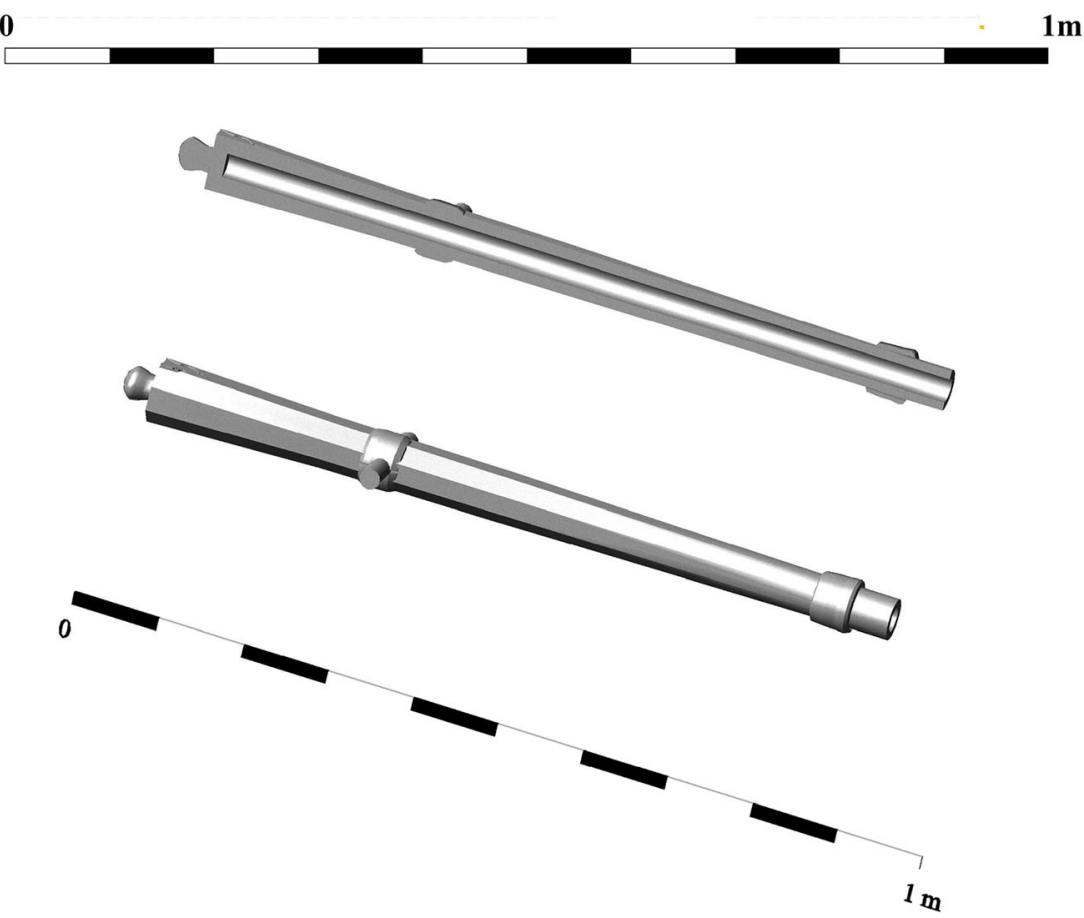

one of the barrel's lateral sides (Fig. 2b). In the breech base, there is a knob. It seems to have been screwed into the base and thus it can also be of a later date. On the bottom side of the breech, there is a $\S$-shaped engraving, perhaps a vestige of an ornamental sprig (Fig. 2c). The touch hole is located on the top side of the breech. Next to it, there are possible traces of an attachment of the priming pan (Fig. 2c). The Museum's inventory card says that the barrel was cast. However, traces of hammering on the entire surface of the artefact naturally imply that the barrel was forged.

Metrical data: - total weight: $12500 \mathrm{~g}(12.5 \mathrm{~kg})$

- total length: $899 \mathrm{~mm}$

- $\quad$ total length of the bore: $823 \mathrm{~mm}$

- external diameter at the breech: $68 \mathrm{~mm}$

- external diameter at the muzzle: $47 \mathrm{~mm}$

_ $\quad$ internal diameter at the muzzle (calibre): $28 \mathrm{~mm}$

_ distance between the muzzle ring and the muzzle: $50 \mathrm{~mm}$

- width of the muzzle ring: $50 \mathrm{~mm}$

- height of the muzzle ring: $6 \mathrm{~mm}$
- distance between the trunnion ring and the breech: $250 \mathrm{~mm}$

- $\quad$ width of the trunnion ring: $45 \mathrm{~mm}$

- height of the trunnion ring: $8 \mathrm{~mm}$

- trunnions' length: 41 and $46 \mathrm{~mm}$

- trunnions' diameter: $24 \mathrm{~mm}$

- $\quad$ knob length: $41 \mathrm{~mm}$

- knob diameter: $38 \mathrm{~mm}$

- distance between the touch hole and the breech base: $25 \mathrm{~mm}$

- diameter of the touch hole: $10 \mathrm{~mm}$

- $\quad$ estimated weight of the projectile: $91.3 \mathrm{~g}$ (cast iron) or $145.1 \mathrm{~g}$ (lead)

\section{Typology, chronology and possible analogies}

Apart from the trunnions and the ring near the muzzle, a special attention must be paid to the groove located between the 


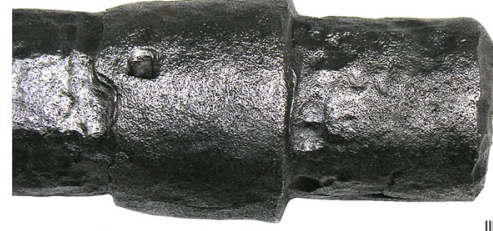

A

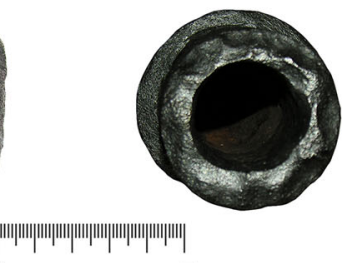

$0 \quad 5 \mathrm{~cm}$
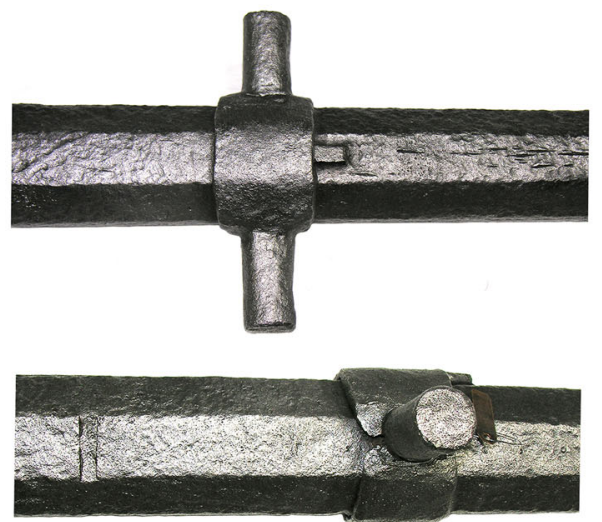

B

$$
0
$$
$30 \mathrm{~cm}$
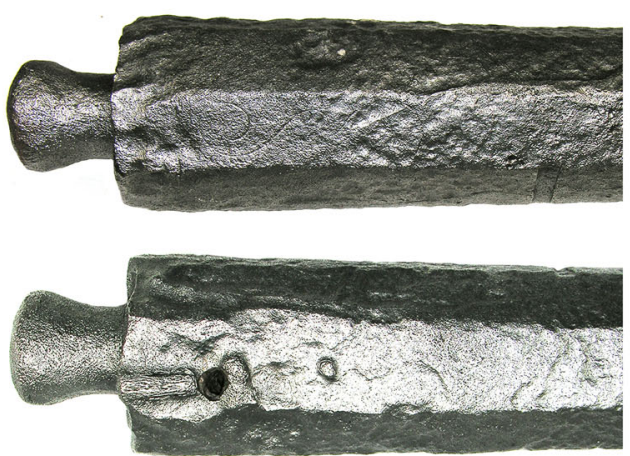

\section{C}

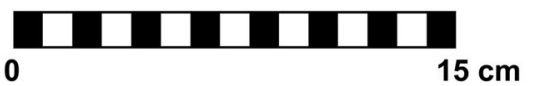

Fig. 2 Gun barrel, Castle Museum in Malbork (MZM/468/MT): a ring near the muzzle (top) and a front view of the muzzle (bottom); $\mathbf{b}$ trunnions, view from below (top) and view from the side. A vertical groove can be seen (bottom); $\mathbf{c}$ knob in the breech and a sprig on the breech part (top) and the touch hole (bottom)

trunnions and the breech. If the barrel is turned around its longer axis so that the groove is up, the touch hole would be located on the right side of the barrel. A rectangular oblong hollowing near the touch hole would indicate a place where the priming pan was originally attached (see Fig. 2c). The groove may have originally served for mounting a backsight of the gun. Such a solution was common in heavy hand-held guns from the turn of the 15th and 16th c. (Prof. Piotr Strzyż, Institute of Archaeology and Ethnology, Polish Academy of Sciences, personal communication on 20 November 2017). It can therefore be assumed that the discussed gun barrel in its original shape was part of a heavy hand-held gun, perhaps a hackbut (? - for a possible reconstruction see Fig. 3). It cannot be excluded that after its barrel had burst (perhaps near the muzzle part), it was repaired and the reinforcing ring was added. This is also suggested by the fact that the cross-section of the barrel near the muzzle is round, unlike in the remaining part of the artefact. At some point in time, trunnions and the breech knob were added and the weapon was thus converted into a light cannon on a carriage. Thus, a search for possible analogies to the discussed gun should go in two directions: (a) heavy hand-held guns with similar positions of touch holes and backsights and (b) light cannons, with some of them having possibly been converted from barrels of earlier origin, with added trunnions.

With regard to the first direction, it seems that the discussed gun in its original shape was a fairly typical heavy hand-held hackbut from the late 15 th-early 16 th $\mathrm{c}$. Reasonable analogies can be found in the München manuscript of the Zeugbuch of Maximilian I King of the Romans from the early 16th c. (Zeugbuch Kaiser Maximilians I. Innsbruck. Bayerische Staatsbibliothek München, Cod. Icon. 222; for a discussion on this manuscript, see Lazar 2017: p. 61-66). Illustrations depict heavy hackbuts with priming pans on their right side. In some cases, backsights are visible (Figs. 4 and 5). As it can be seen in Fig. 4, weapons of this kind were operated by teams of two soldiers. One of them aimed the gun, while the other fired it with a slow match (on this issue, see also, e.g. Lazar 2017: p. 65; Strzyż 2014a: p. 57-59; Szymczak 2004: p. 41-45, 59; Głosek 1990: p. 158; Forrer 1905).

Furthermore, artefacts with analogous traits are also known. The touch hole on the right side of the breech can be seen on a heavy iron-forged hackbut which possibly comes from the vicinity of Neuss in Rhineland. The find may be related to the siege of Neuss in 1474 by Charles the Bold of Burgundy. Its total length is $1070 \mathrm{~mm}$, it weighs c. $12.5 \mathrm{~kg}$, and its calibre is $34 \mathrm{~mm}$. This gun is also provided with a backsight, albeit of a different construction (it is a notch in a ring at the end of the breech) (Engel 1900-1902: p. 302, Figs. 3 and 6). Analogous positions of the touch holes and the backsights can also be seen in the case of two heavy iron hackbuts from the National Museum in Prague. What differs them from the discussed barrel is the fact that their cross-sections are round (Fig. 6) (Figel' et al. 2010: p. 480, 482, Fig. 7). On the basis of the depictions in

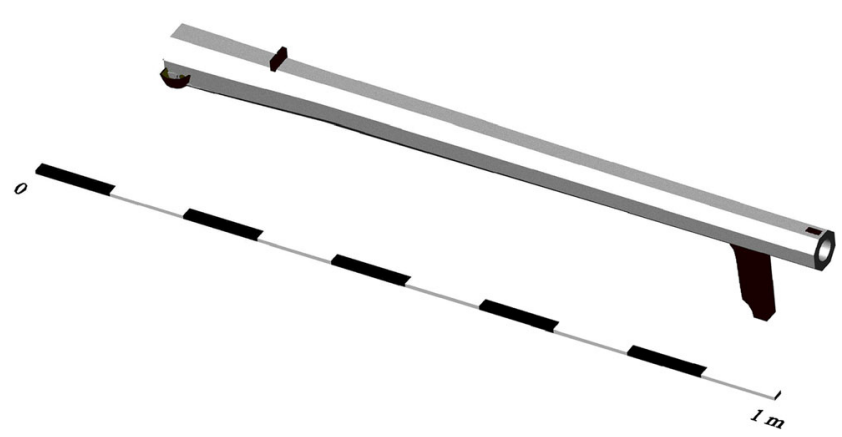

Fig. 3 Gun barrel, Castle Museum in Malbork (MZM/468/MT) reconstruction of the original shape. Reconstructed parts (priming pan, backsight, foresight and hook) are marked with a different colour 


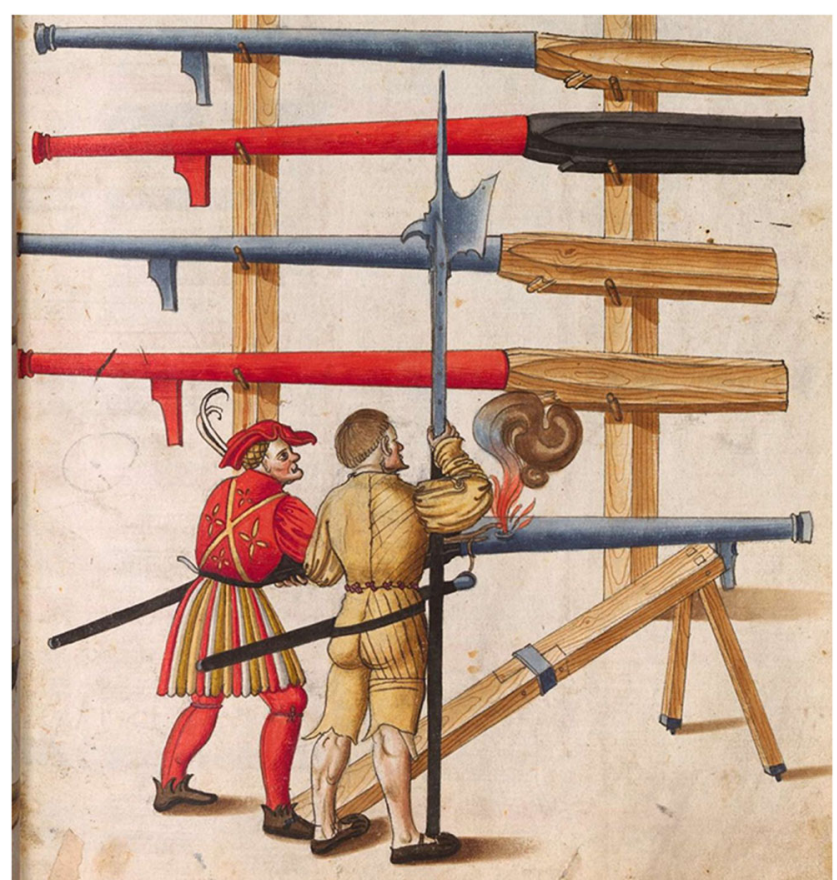

Fig. 4 Heavy iron-forged hackbut with a priming pan on the right side of the breech. After Zeugbuch, c. 1502, 73r. Copyright Bayerische Staatsbibliothek München

the Zeugbuch, a late 15 th or early 16 th c. chronology can safely be assumed for the $\mathrm{m}$.

A good example of a heavy iron-forged hand-held gun whose barrel is octagonal in cross-section is offered by a weapon from the Armoury of the Solovetsky Monastery in Russia, now in the Military-Historical Museum of Artillery, Engineer and Signal Corps in St Petersburg in Russia (inv. No. $1 / 22$ ). This gun is dated to the first half of the 16th c. The touch hole is located on the right side of the breech. There is

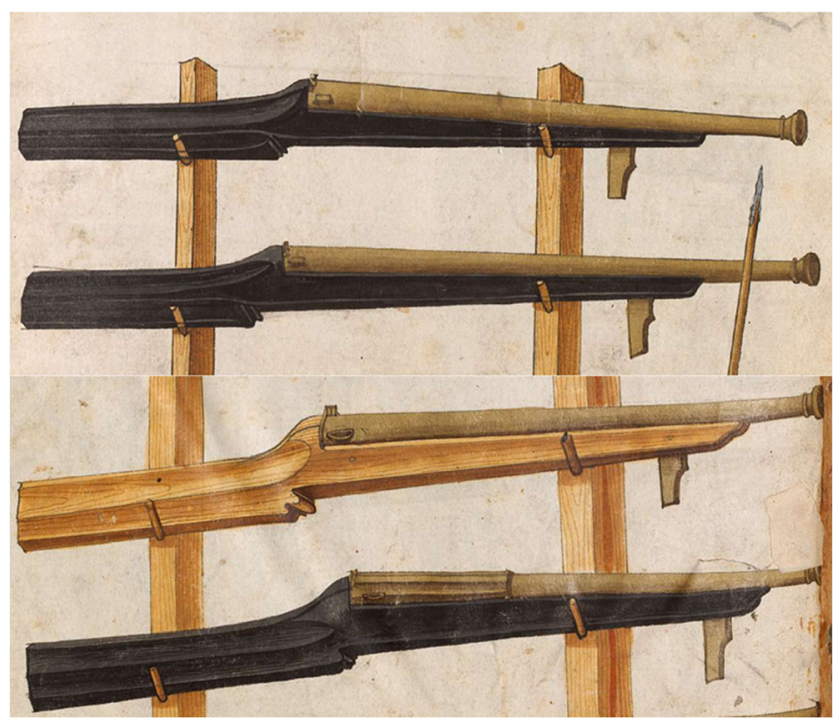

Fig. 5 Heavy brass hackbuts with priming pans on the right side of the breech and with backsights. After Zeugbuch, c. 1502, 72r (top), 72v (bottom). Copyright Bayerische Staatsbibliothek München

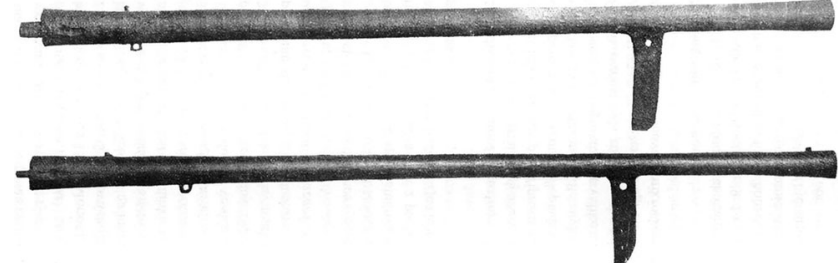

Fig. 6 Iron hackbuts from the National Museum in Prague. After Figel' et al. 2010: p 482, Fig. 7

a short tang in the breech base and a catch can be seen in the bottom side of the breech. Both parts were used for mounting the barrel in the stock. Furthermore, there is a wide ring in the muzzle part of the gun (Makovskaya 1992: p. 43, 125, Fig. 37). It is perhaps a trace of repair. The ring is located in a place where hooks were often attached to barrels (cf. Fig. 6).

The Brukenthal National Museum in Romania holds a heavy iron-forged hackbut of unknown provenance, possibly dated to the late 15 th-first quarter of the 16th $\mathrm{c}$. The barrel is $103 \mathrm{~cm}$ long, it weighs $15 \mathrm{~kg}$ and its calibre is $2.1 \mathrm{~cm}$. The cross-section of the barrel is octagonal in the breech part, and then it becomes round. The muzzle ends with an octagonal crown-shaped reinforcement. The barrel is provided with a backsight and a foresight. A priming pan and the touch hole are located on the right side of the breech (Strzyż 2014a: p. 337, Pl. LVII.1-7, cat. No. 171).

An octagonal cross-section of the barrel can also be seen in the case of an iron-forged hackbut muzzle fragment from Cvilín in Bohemia. The find is kept in the Silesian Museum in Opava and is dated to c. 1474. Its calibre is $2.8 \mathrm{~cm}$ (Strzyż 2014a: p. 342, Pl. LXII.4-5, cat. No. 74). Similar traits are notable in the case of some other guns, e.g. a late 15th c. hackbut of unknown provenance from the collection of the Military History Institute in Prague. The touch hole and the priming pan are located on the right side of the breech. The barrel is octagonal in cross-section (Strzyż 2014a: p. 295, Pl. XV.3, cat. No. 56; for other cases see, e.g., ibid.: p. 300-301, Pl. XX-XXI, cat. Nos. 30-33, p. 307, Pl. XXVII, cat. No. 42, p. 308, Pl. XXVII, cat. No. 43).

A further analogy is offered by an iron-forged Danish hackbut (c. 1515) in the collection of the Danish National Museum of Military History. The barrel is octagonal in cross-section and is $1455 \mathrm{~mm}$ long. Its weight is $10.49 \mathrm{~kg}$ and the calibre is $19.2 \mathrm{~mm}$. It is provided both with a backsight and a foresight. Engraved ornament can be seen in the breech part, above the hook and in the muzzle part. The touch hole is located on the right side of the breech (McLachlan 2010: p. 6). Other similar iron-forged weapons are held in the Croatian History Museum. The first one is a hackbut of a possibly early 16th date (or earlier), whose barrel is octagonal in cross-section. Its length is $1225 \mathrm{~mm}$, its calibre is $25 \mathrm{~mm}$ and its weight is $9.2 \mathrm{~kg}$. The barrel is provided with a backsight and a foresight (McLachlan 2010: p. 68-69, No. 1). The second one (length $1060 \mathrm{~mm}$, calibre $20 \mathrm{~mm}$, weight $8.2 \mathrm{~kg}$ ) is very 
similar both with regard to its shape and chronology. The touch hole is located on the right side of the breech. The backsight did not survive, but a groove where it was originally attached is visible on top of the breech (McLachlan 2010: $\mathrm{p}$. 68-69, Nos. 2-3). The same can be seen in the case of the third hackbut (length $1335 \mathrm{~mm}$, calibre $23 \mathrm{~mm}$, weight $10.9 \mathrm{~kg}$ ). This gun is also of an early 16th or earlier date (McLachlan 2010: p. 68-69, Nos. 5-6).

In the light of these analogies, it can be proposed that the discussed artefact may have originally been a heavy hackbut. A chronology of the late 15th-early 16th c. can be assumed, bearing in mind the fact that such guns could remain in use for longer (see Strzyż 2014a: p. 57-60, 62-64). This date seems to be additionally suggested by the location of the touch hole. Touch holes of the earliest firearms were generally placed on the top of the breech. This was inconvenient for the user, as smoke and fire rendered aiming difficult. Probably, c. 1450 touch holes commenced to be placed on the side of the breech (see, e.g. Strzyż 2014a: p. 54-56, Strzyż 2011: p. 23, 42, 45; Makovskaya 1992: p. 16-17, 29; see also Oakeshott 2000: p. 34; cf. Głosek 1990: p. 158 and Mielczarek 1998: p. 62). Furthermore, Strzyż notes that separate priming pans commenced to be attached to hackbut breeches at the turn of the 15th and 16th c. (Strzyż 2014a: p. 63).

It is more difficult to provide analogies to the discussed gun in its present shape. A reasonable example is offered by a copper alloy gun of a c. 1470 date, taken as booty by the Swiss in their wars against Burgundy. The artefact is stored in the Historical Museum in Basel in Switzerland. Its overall length is $985 \mathrm{~mm}$ and its calibre is $29 \mathrm{~mm}$. The barrel is octagonal in cross-section and the touch hole is located on top of the breech. In the central part of the barrel, there is an iron band with trunnions. It is believed to be a later addition. The artefact may have originally been a hand-held gun or coulverine. After the conversion, it was mounted on a ship's carriage, perhaps before 1709 (Smith and DeVries 2005: p. 270-271; see also Strzyż 2014a: p. 78).

Another interesting case is posed by a terrace-gun (a light cannon used for defence of fortifications, see Strzyż 2014a: p. 72) from the Southern Moravian Museum in Znojmo (inv. No. 516) in the Czech Republic. The gun is dated to the third or fourth quarter of the 15th c. Its iron-forged barrel is octagonal in cross-section. The touch hole is located on top of the breech. Iron trunnions attached with the use of a band can be seen in the central part of the barrel. The total length of the barrel is $95.5 \mathrm{~cm}$ and its calibre is $36-38 \mathrm{~mm}$. The barrel is now mounted in a later stock. An addition of trunnions enabled terrace-guns to be mounted on wheeled carriages, thus improving weapons' mobility (Strzyż 2014a: p. 77-79, Tab. 10, Pl. LXXXII, cat. No. 68).

An interesting gun is stored in the Historical Museum in Sanok in Poland (inv. No. HMS/H/1690). The total length of the iron barrel is $234 \mathrm{~cm}$ and its calibre is $48 \mathrm{~mm}$. The cross- section of the barrel is octagonal in the breech part and round in the muzzle part. In the mid-length of the barrel, there are two forge-welded trunnions. The touch hole is located on top of the breech (Strzyż 2014b: p. 64-65, Fig. 8). Strzyż mentions several analogies to the gun from Sanok. All these firearms are small calibre $(40-50 \mathrm{~mm})$ cannons referred to as falconets. They have long barrels (up to $2.5 \mathrm{~m}$ ) which are octagonal in cross-section and are provided with trunnions. They are mounted on light wheeled carriages. The chronology of these guns falls within the 16th c. (Strzyż 2014b: p. 65-68, Figs. 2, 3, 4, see also Strzyż 2011: p. 42-44). On the basis of these analogies, Strzyż proposes to classify the Sanok gun as either a small falconet or (less probably) a serpentine and date it to the first half of the 16th c. (Strzyż 2014b: p. 69-71). The barrels of these guns are more than two times longer than that of the Castle Museum artefact and their calibres clearly place them within the category of light artillery. On the other hand, they may serve as a convenient pattern for what the Castle Museum gun was intended to be after the conversion.

A certain analogy could also be seen in a mid-16th c. Spanish light naval cannon of bastard esmeril type, a socalled Matacapitanes (captain-killer). The name implies that weapons of this kind were intended to be used against enemy officers, usually protected with good-quality armour. This cannon is made from bronze and is provided with trunnions. The trunnions are mounted in a Y-shaped holder with a pivoting shaft, so that the barrel can be moved both in the horizontal and vertical plan. The total length of the barrel is $82 \mathrm{~cm}$ and the calibre is $38.8 \mathrm{~mm}$ (Fondevilla Silva and Sánchez Baena 2012: p. 185-210, Figs. 6, 5, 7). Of similar shape is a gun which is referred to as a small falconet. It was manufactured in Kiev in 1673 as is held in the MilitaryHistorical Museum of Artillery, Engineer and Signal Corps in St Petersburg in Russia (inv. No. 10/101). Its total length is $932 \mathrm{~mm}$, its calibre is $35 \mathrm{~mm}$ and its weight is $20 \mathrm{~kg}$. The barrel is lavishly ornamented and provided with two slender lifting handles (so-called dolphins). It is mounted on a pivoting Y-shaped holder (Malčenko 2011: p. 48-49, cat. No. 14, Pl. 14).

\section{Technological examinations}

The first series of examinations was carried out in the Laboratory for Archaeometallurgy and Conservation of the Institute of Archaeology of the Jagiellonian University in Kraków, Poland. A wedge-shaped sample was taken from the muzzle of the barrel. It must be said here that the metal in this part of the barrel does not necessarily match that of the gun it its original shape, as the muzzle part of the barrel was reforged. This process may have influenced the chemical composition of slag inclusions in the metal. However, due to conservation reasons, it was the only location where sampling 
was allowed. The aim of the examinations was to identify the material from which the barrel was made and to analyse slag inclusions (SI) in the metal.

\section{Research methods}

The sample was mounted in Electro-MIX conductive resin. It was ground on sandpapers (gradations of 800, 1000, 1200 and 2000 grits) and polished using diamond pastes $(9,1$ and $0.5 \mu \mathrm{m})$. The polished surface of the sample which corresponds to the cross-section of the barrel wall was etched with $4 \%$ nital in order to reveal its microstructure. Microstructure observations were carried out using a Leica DMLM optical microscope. The content of $\mathrm{C}$ was approximately assessed on the basis of microscopic observations. Hardness tests were carried out using the Vickers method with a $10 \mathrm{kG}(98 \mathrm{~N})$ load. Microanalyses of slag inclusions were done using a Tescan Vega Super 3 scanning microscope with an EDS type spectrometer (accelerating voltage of $20 \mathrm{kV}$ ). A second series of microanalyses of slag inclusions was done in the National Centre for Nuclear Research in Otwock, Poland. Examinations were carried out with a Carl Zeiss EVO MA 10 scanning microscope equipped with an EDX type Bruker Quantax spectrometer, with accelerating voltage of $20 \mathrm{kV}$ and spectral resolution of $123 \mathrm{eV}$. In both series of analyses, a result for each slag inclusion is an average of several (usually four) measurements in different spots. No prominent differences between measurements obtained with these two different instruments were noticed, and therefore, the results of both series of analyses were used. As the metallographical examinations did not demonstrate the presence of several pieces of metal (see below), it can be assumed that the results of the analyses are representative for the entire sample.

\section{Microscopic examinations and the EDS analysis of slag inclusions}

The spot of sampling, a macroscopic image of the sample surface with spots of microscopic observations (1-2) and a schematic distribution of structural components and hardness tests (HV10) can be seen in Fig. 7a, b. The microstructure in the sample changes from ferritic areas with precipitations of ternary cementite (Figs. 7c, 8c-f and 9c) to ferritic-pearlitic areas which correspond to soft steel with the carbon content of 0.1-0.2\% C (Figs. 7c, 8a, b, 9a-e, and 10a-d). Only in one zone (zone 1a in spot 1), a pearlitic-ferritic microstructure can be seen. It corresponds to semi-hard steel with the carbon content of $0.3-0.5 \% \mathrm{C}$ (Fig. $7 \mathrm{c}-\mathrm{e}$ ). The metal contains numerous slag inclusions (Figs. 7c and 9a). These are mainly multiphase ones and they locally form clusters (Figs. 9d and 10c). A morphology of the slag inclusions can be seen in Figs. 8b, $\mathrm{f}$, $9 \mathrm{e}$ and $10 \mathrm{~d}-\mathrm{f}$. The X-ray EDS analysis of multi-phase slag inclusions (SI1, SI2, SI3 and SI4) in the metal demonstrated that bright globular particles chiefly contain $\mathrm{Fe}$ and $\mathrm{O}$. These particles are wüstite precipitations. The matrix of the multiphase slag inclusions is composed of $\mathrm{Fe}, \mathrm{O}, \mathrm{Si}, \mathrm{Al}, \mathrm{Ca}, \mathrm{K}, \mathrm{Mg}$, $\mathrm{P}, \mathrm{S}$ and Ti. The matrix does not contain $\mathrm{Mn}$, Ti is present sporadically, while $\mathrm{S}$ occurs more often. Such a composition can be a result of both the ore composition and the technology of smelting. On the basis of the technological analyses, it can be supposed that the barrel was made from unevenly carburised soft bloomery steel with the carbon content of $0.1-0.2 \%$ C. The hardness varies between 97 and 158 HV10, which is a pretty typical result for this kind of metal. Furthermore, due to difficulties in obtaining high-quality hard steel, it seems that the choice of softer metal (and thus less prone to breaking) was well-founded concerning the utilitarian quality of the barrel. Obviously, such a barrel hand to be thick enough to secure proper toughness.

\section{Identification of the smelting process using slag inclusion analysis}

Slag inclusions in iron vary a great deal with regard to their chemical composition. Major elements are $\mathrm{Fe}, \mathrm{O}, \mathrm{Si}, \mathrm{Al}, \mathrm{Mg}$, $\mathrm{Ca}, \mathrm{K}$ (and sometimes $\mathrm{P}$ and $\mathrm{S}$ ), while $\mathrm{Ti}, \mathrm{V}, \mathrm{Na}, \mathrm{Ba}$ and many others are found as minor components. In spite of differences in the contents of individual elements and their oxides, certain regularities can be noted. FeO-rich slag inclusions are usually located in ferritic areas, while $\mathrm{SiO}_{2}$-rich inclusions can be mainly found in pearlitic areas. These differences are due to the fact that these inclusions come from different phases of smelting. At lower temperatures and with a limited reducing power of the $\mathrm{CO} / \mathrm{CO}_{2}$ gas, the metallic phase is formed as ferritic iron which contains $\mathrm{FeO}$-rich slag. When the temperature rises and the reducing power of the $\mathrm{CO} / \mathrm{CO}_{2}$ gas increases, it comes to carburisation of the metallic phases. The accompanying slag inclusions are poor in $\mathrm{FeO}$. There are usually several transitional stages between these two cases. In spite of these differences, it is possible to observe a more or less steady ratio between selected oxides, such as $\mathrm{MnO} / \mathrm{SiO}_{2}$, $\mathrm{K}_{2} \mathrm{O} / \mathrm{Al}_{2} \mathrm{O}_{3}$ or $\mathrm{CaO} / \mathrm{Al}_{2} \mathrm{O}_{3}$ (Buchwald and Wivel 1998, 74 77; see also Buchwald 2005, 2008).

Dillmann and L'Héritier (2007) proposed a method to distinguish between direct (bloomery) and indirect (blast furnace and refining) smelting processes using results of analyses of the chemical composition of slag inclusions. This method is based on the observation that the composition of slag inclusions in iron is influenced both by materials which are part of a given smelting operation and by the nature of the ironmaking process. With regard to the bloomery process, the content of $\mathrm{Fe}$ and $\mathrm{P}$ oxides in slag inclusions is conditioned by the efficiency of reduction. On the other hand, in the blast furnace process, the chemical composition of slag inclusions in wrought (refined) iron mainly results from conditions of the fining process. Some oxides (referred to as NRCs or non-reduced compounds) do not 
Fig. 7 Microstructures on the surface of the sample from the gun barrel, MZM/468/MT: a spot of sampling and the macrostructure of the sample with spots of microscopic observations (1-2); b schematic depiction of the distribution of carbon and hardness tests HV10 (F-ferrite, $\mathrm{P}$-pearlite, $\mathrm{C}_{\mathrm{III}}$-ternary cementite); $\mathbf{c}$ microstructure of the sample in spot 1 ; $\mathbf{d}$ pearliticferritic microstructure, zone $1 \mathrm{a}$ in spot $1 ; \mathbf{e}$ dark colonies of partially degenerated pearlite against the background of bright ferrite, zone 1a in spot 1

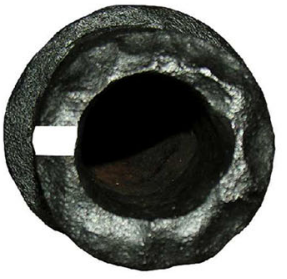

|||||||||||||||||||||||||||||||||||||||||||||||||||||

o

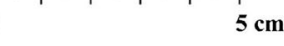

a)

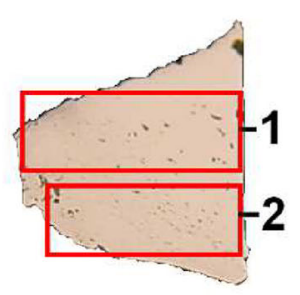

$0.1-0.2 \% \mathrm{C}$

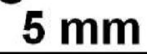

b)

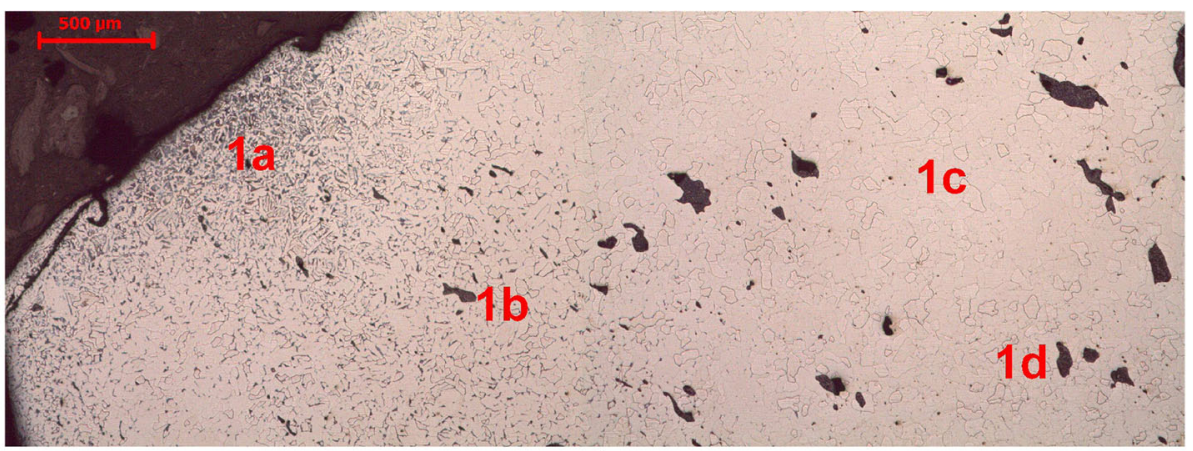

c)

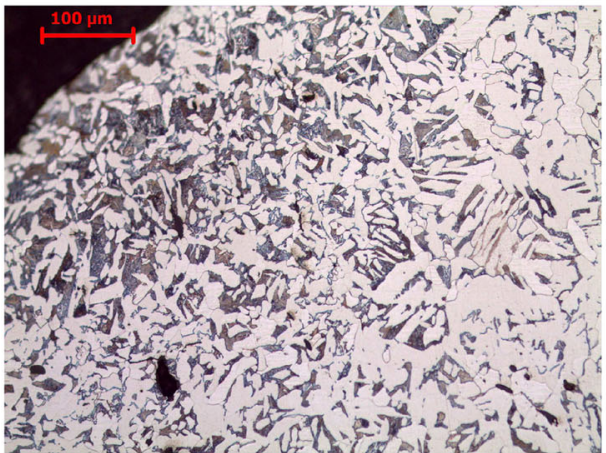

d)

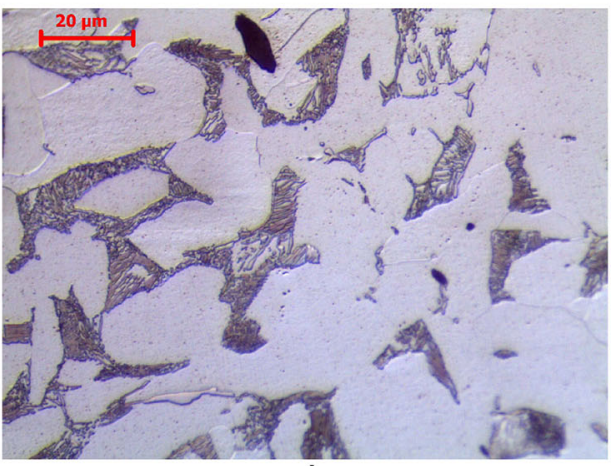

e) undergo reduction in the course of the smelting process or undergo a complete reoxidation in its last phase. For the purpose of identification of the smelting process, the most useful NRCs are $\mathrm{MgO}, \mathrm{Al}_{2} \mathrm{O}_{3}, \mathrm{SiO}_{2}, \mathrm{~K}_{2} \mathrm{O}$ and $\mathrm{CaO}$. The ratio of these NRCs in slag inclusions is in most cases relatively constant. NRC ratios will be roughly the same in the case of a majority of slag inclusions in iron from different stages of manufacture (from blooms to semi-products). Thus, the NRC ratio could be considered a "signature" of a given smelting system, which is understood as an operation with the use of ore, fuel, fluxes and furnace lining (Dillmann and L'Héritier 2007: p. 18101815, Figs. 2, 3, 4; see also L'Héritier et al. 2013: p. 410412; Disser et al. 2014: p. 316; Blakelock et al. 2009: p. 1747-1748; for an earlier discussion on NRCs, see, e.g. Buchwald 2008, 2005; Buchwald and Wivel 1998).

NRC ratios may vary between individual inclusions. The influence of additives in subsequent stages of manufacture can influence the composition of new inclusions so that it will be different than that of smelting-related inclusions. Therefore, in the case of artefacts which went through many manufacturing stages, there is a high probability of contamination of slag inclusions with additives. In such artefacts, the number of smelting-related slag inclusions is more likely to be much lower than the number of forging-related inclusions. This means that this method of identification can be best used for artefacts which were not processed in too many stages of manufacture (Dillmann and L'Héritier 2007: p. 1814-1815).

The recommended analytical procedure includes the following stages:

- identification of zones in the sample with varying contents of $\mathrm{C}$ and $\mathrm{P}$ and identification of possible welding lines. Additive-derived slag inclusions in welding lines are to be analysed, if present

- a minimum of 40 slag inclusions in each zone is to be analysed 
Fig. 8 Microstructures on the surface of the sample from the gun barrel, MZM/468/MT: a ferritic-pearlitic microstructure and slag inclusions, zone $1 \mathrm{~b}$ in spot 1 ; b multi-phase slag inclusion against the background of ferritic-pearlitic microstructure, zone $1 \mathrm{~b}$ in spot 1 ; $\mathbf{c}, \mathbf{d}$ ferrite with precipitations of ternary cementite in grain borders, zone $1 \mathrm{c}$ in spot 1 ; e, f multi-phase slag inclusions against the background of ferritic microstructure, zone $1 \mathrm{~d}$ in spot 1

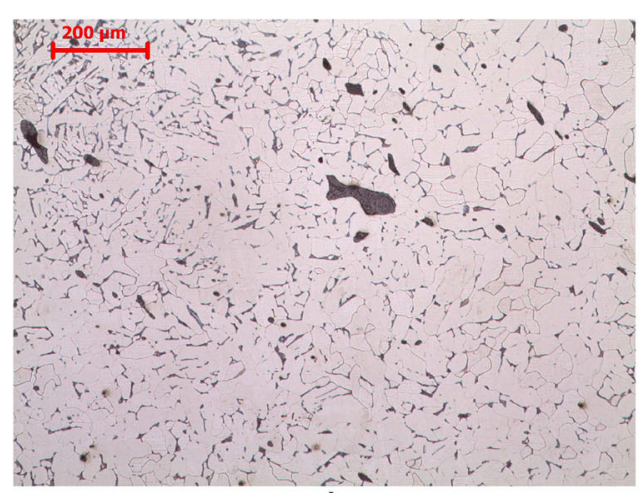

a)

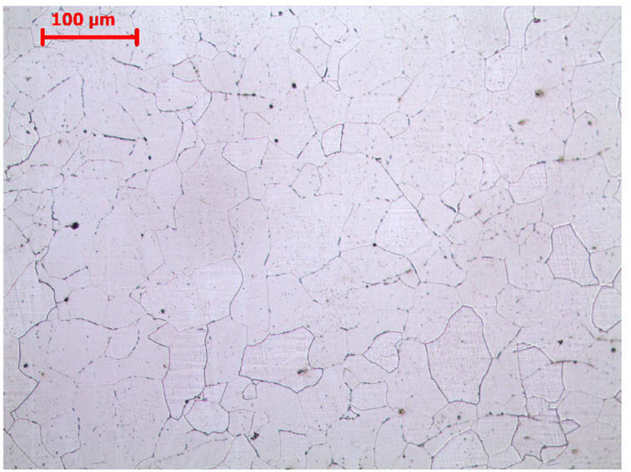

c)

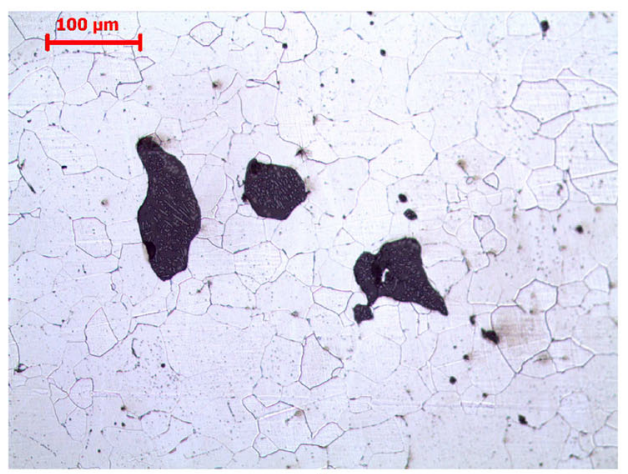

e)

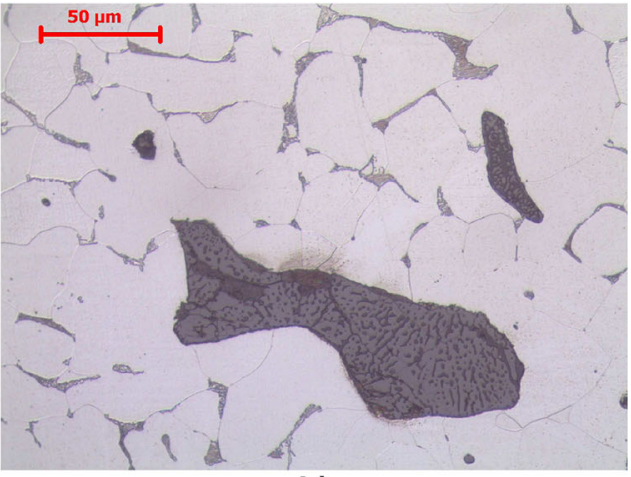

b)

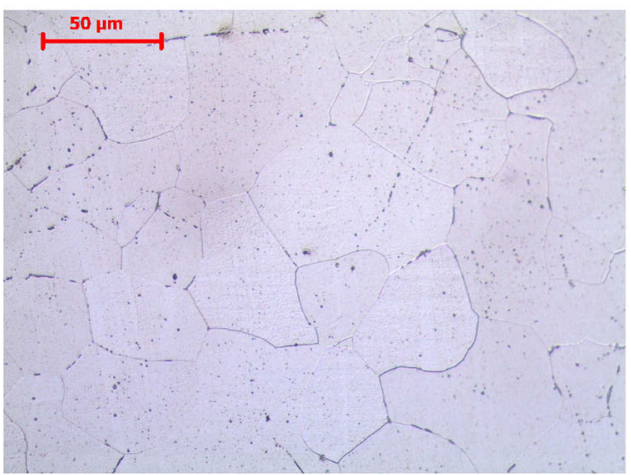

d)

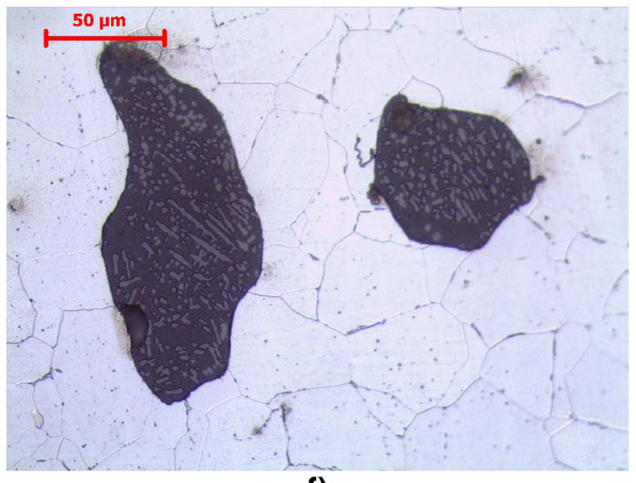

- contents of $\mathrm{Na}_{2} \mathrm{O}, \mathrm{MgO}, \mathrm{Al}_{2} \mathrm{O}_{3}, \mathrm{SiO}_{2}, \mathrm{P}_{2} \mathrm{O}_{5}, \mathrm{SO}_{3}, \mathrm{~K}_{2} \mathrm{O}$, $\mathrm{CaO}, \mathrm{TiO}_{2}, \mathrm{Cr}_{2} \mathrm{O}_{3}, \mathrm{~V}_{2} \mathrm{O}_{5}, \mathrm{MnO}, \mathrm{FeO}(\mathrm{wt} \%$ ) are calculated

- one plots the slag inclusion's composition for each NRC ratio (usually $\% \mathrm{Al}_{2} \mathrm{O}_{3} / \% \mathrm{SiO}_{2}, \% \mathrm{~K}_{2} \mathrm{O} / \% \mathrm{CaO}$ and $\left.\% \mathrm{MgO} / \mathrm{Al}_{2} \mathrm{O}_{3}\right)$ and fits it by a linear model passing through zero. If the determination coefficient $R^{2}$ equals to or is over 0.7 , the ratio can be considered constant. In case $R^{2}$ is less than 0.7 , but a linear behaviour can still be seen for a majority of inclusions, the erratic ones are eliminated and the ratio is determined again

- a "surface weighted average composition" for all elements or oxides must be calculated. The aim is to include not only NRCs, but also other elements (such as $\mathrm{P}$ or Fe). It is calculated using all the analysed inclusions in a given zone or in the entire artefact, after the removal of inclusions which display abnormal NRC ratios. The "weighted content" includes the ratio between the surface area of a given inclusion and the total surface of all the analysed inclusions. The following formula is used to calculate it (Eq. 1):

$\% E^{*}=\sum_{i=1}^{n}\left(\% E_{i} \times \frac{S_{i}}{S_{T}}\right)$

$\% \mathrm{E}^{*} \quad$ weighted content of the considered element or oxide

$\% \mathrm{E}_{\mathrm{i}}$ mass content of the element or oxide in the i slag inclusion (SI)

$\mathrm{S}_{\mathrm{i}} \quad$ surface of the analysed SI i

$\mathrm{S}_{\mathrm{T}} \quad$ total surface of all the analysed SI

$\mathrm{n}$ total number of inclusions 
Fig. 9 Microstructures on the surface of the sample from the gun barrel, MZM/468/MT: a microstructure in spot $2 ; \mathbf{b}, \mathbf{c}$ ferritic-pearlitic microstructure, partially degenerated colonies of pearlite, zone 2a in spot 2; $\mathbf{d}, \mathbf{e}$ bands of multi-phase slag inclusions against the background of ferrite, zone $2 b$ in spot 2

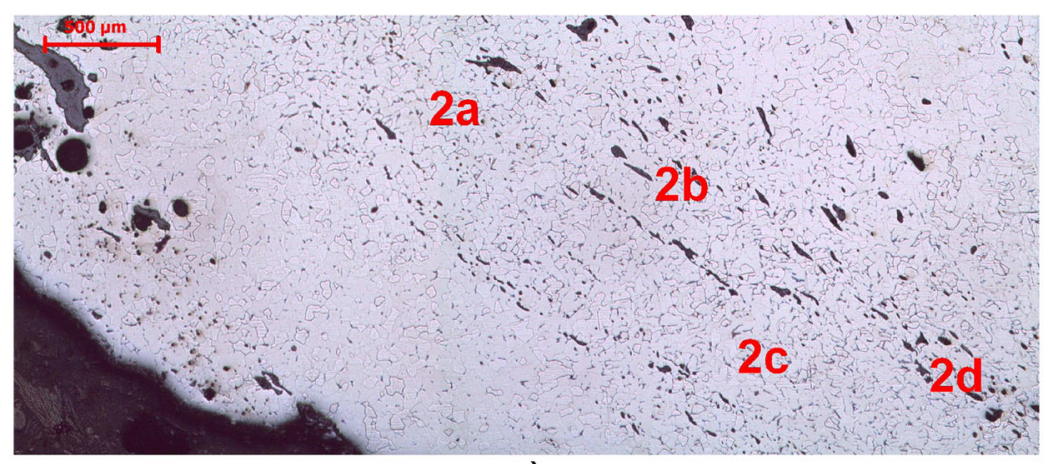

a)

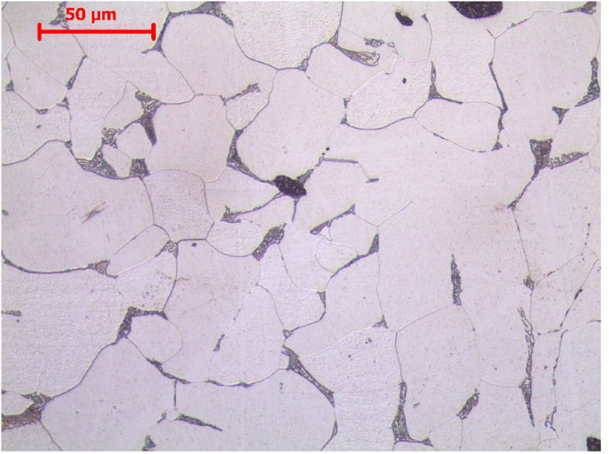

b)

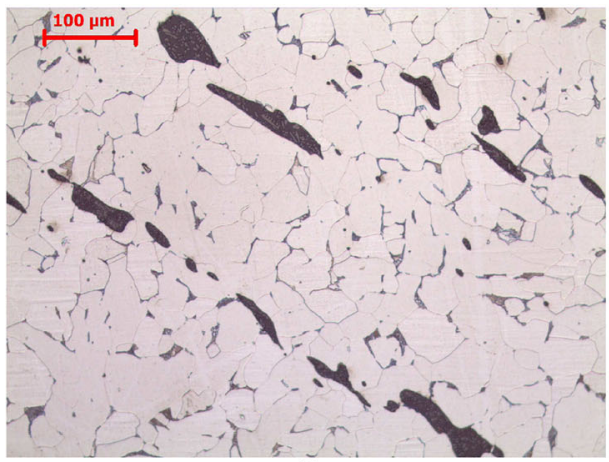

d)

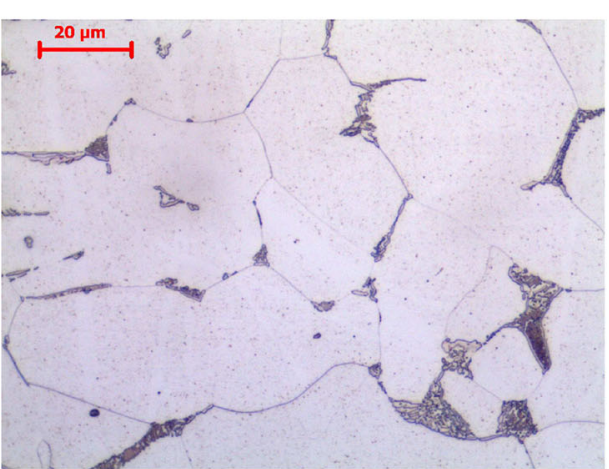

c)

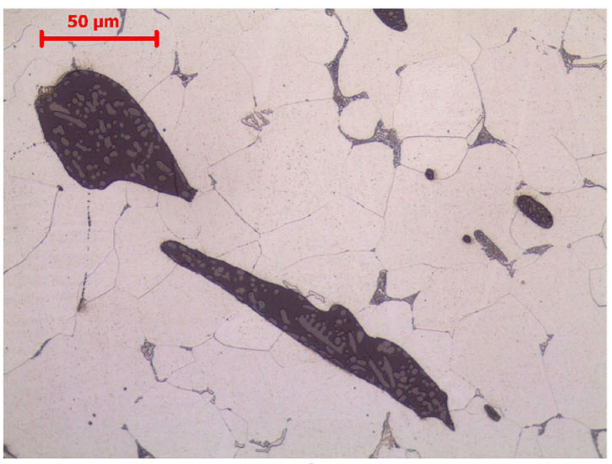

e)
- for the sake of distinction between the weighted content and the normal content, the former is marked with an * (e.g. $\% \mathrm{Al}_{2} \mathrm{O}_{3}{ }^{*}$ ). After the abnormal inclusions are eliminated, the evaluation of the NRC ratio using linear regression and the ratio of weighted contents produces identical results (Dillmann and L'Héritier 2007: p. 1811, 18151817; see also L'Héritier et al. 2013: 410-412).

Another method of discrimination between smeltingderived slag inclusions and those related to other stages of manufacture was proposed by Charlton et al. (2012). It is based on modelling of relationships between chemical groups of slag inclusions, as shown in Table 1.

On the basis of these relationships, it can be supposed that groups of slag inclusions located at the upper extremes of variables which display a strong positive correlation may derive from parent materials whose chemical composition is dominated by the same variables (Table 2).

In order to analyse and display relationships discussed above, a principal component analysis (PCA) is used. In this method, a new set of uncorrelated variables is drawn on a

Table 1 Relationships between oxides in NRCs and the chemical composition of their parent materials (after Charlton et al. 2012: p. 2283, Table 1)

\begin{tabular}{lllllllll}
\hline & $\mathrm{MgO}$ & $\mathrm{Al}_{2} \mathrm{O}_{3}$ & $\mathrm{SiO}_{2}$ & $\mathrm{~K}_{2} \mathrm{O}$ & $\mathrm{CaO}$ & $\mathrm{TiO}_{2}$ & $\mathrm{SrO}$ & $\mathrm{BaO}$ \\
\hline Bloomery slag & $*$ & $*$ & $*$ & $*$ & $*$ & $*$ & $*$ & $*$ \\
Clay & & $*$ & $*$ & $*$ & & $*$ & & $*$ \\
Fuel ash & $*$ & & & $*$ & $*$ & & $*$ & \\
Smithing flux & & & $*$ & & & & & \\
\hline
\end{tabular}


Fig. 10 Microstructures on the surface of the sample from the gun barrel, MZM/468/MT: a, b dark colonies of partially degenerated pearlite against the background of bright ferrite, zone $2 \mathrm{c}$ in spot 2 ; c ferritic-pearlitic microstructure and a cluster of slag inclusions, zone $2 \mathrm{~d}$ in spot 2 ; d multi-phase slag inclusions and colonies of partially degenerated pearlite against the background of ferrite, zone $2 \mathrm{~d}$ in spot 2; e, f examples of diversified morphology of multi-phase slag inclusions in the metal of the gun barrel

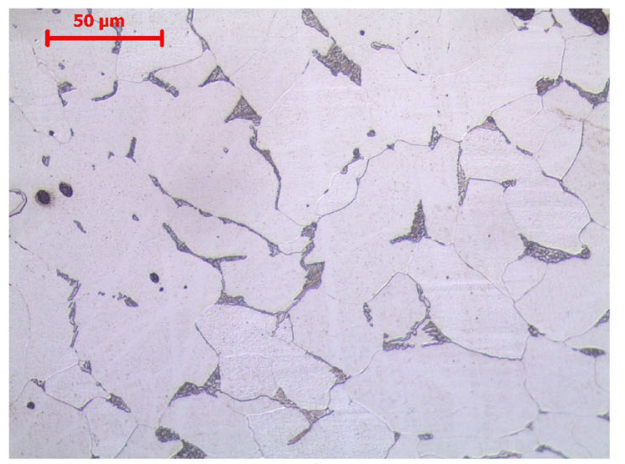

a)

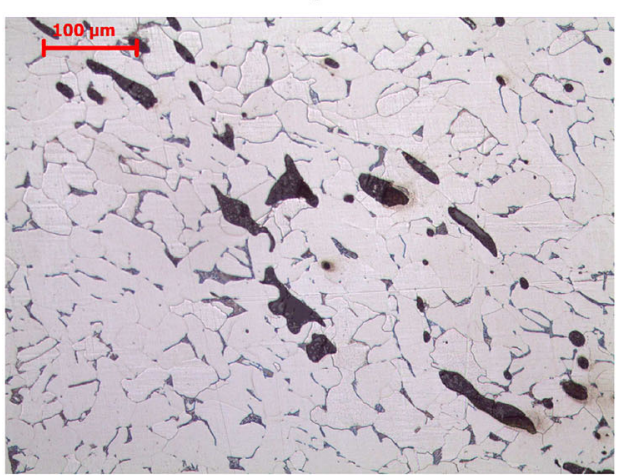

c)

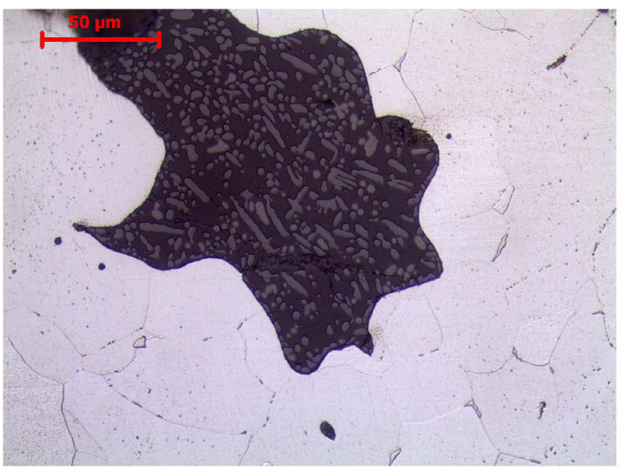

e)

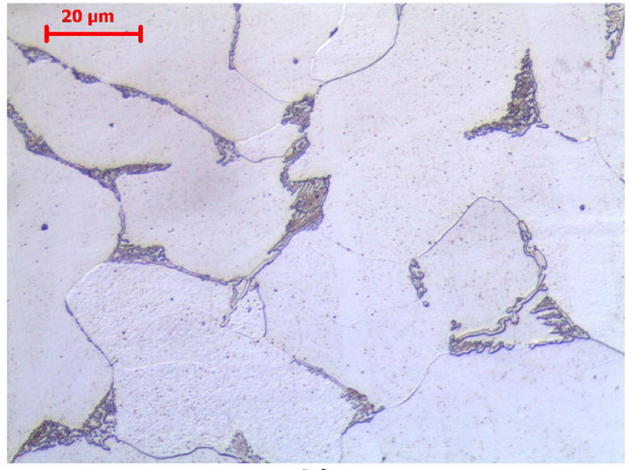

b)

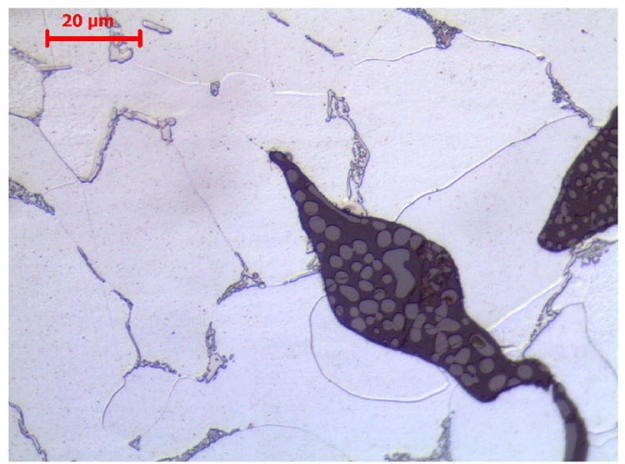

d)

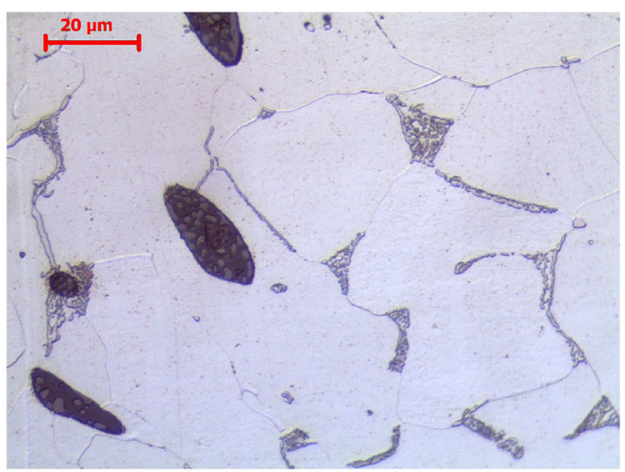

f) series of axes from the assemblage of original data. Each new axis or principal component (PC) is a linear combination of the original variables (in this case- $\mathrm{NRCs}$ ), and it represents the greatest part of variation within the assemblage. The second axis or PC demonstrates the greatest part of the remaining variation, but is constrained to be orthogonal to PC 1 . All other axes or principal components follow the same pattern. It is possible to represent the greatest part of the variation in the dataset using the first two or three axes. Influence of a given variable on a given PC is expressed by its loading. It varies between -1 and 1 and is equivalent to the correlation coefficient $(r)$. Loadings are displayed as vectors starting from the origin on a graph with two axes or PCs. Data points representing individual observations in the $\mathrm{PC}$ space can be interpreted with regard to their positions relative to the vectors (Charlton et al. 2012: p. 2281-2283).
Before running the PCA, raw data must be transformed to remove the dilution effect caused by non-modelled compounds and to provide all the oxides in question with a more or less equal weight. One way to deal with the dilution issue is to transform original variables into subcompositional ratios. Each subcompositional ratio is the measured composition of a given compound divided by the sum of all compounds which are taken into consideration. In order to give an approximately equal weight to all the analysed compounds, several transformations can be applied. Out of many possible choices, Charlon et al. propose to calculate - logged values $\left(-\log \left[x_{i j}\right]\right)$ of subcompositional ratios for relevant NRCs. The transformed values of NRCs are used in further analyses (Charlton et al. 2012: p. 2283-2884).

After the PCA is carried out, raw PC scores are examined with cluster analysis (or agglomerative hierarchical 
Fig. 11 Gun barrel, MZM/468/ MT: identification of smeltingderived slag inclusions with the agglomerative hierarchical clustering (dissimilarity type, Euclidean distance, weighted pair-group average agglomeration) (top) and the principal component analysis (bottom)
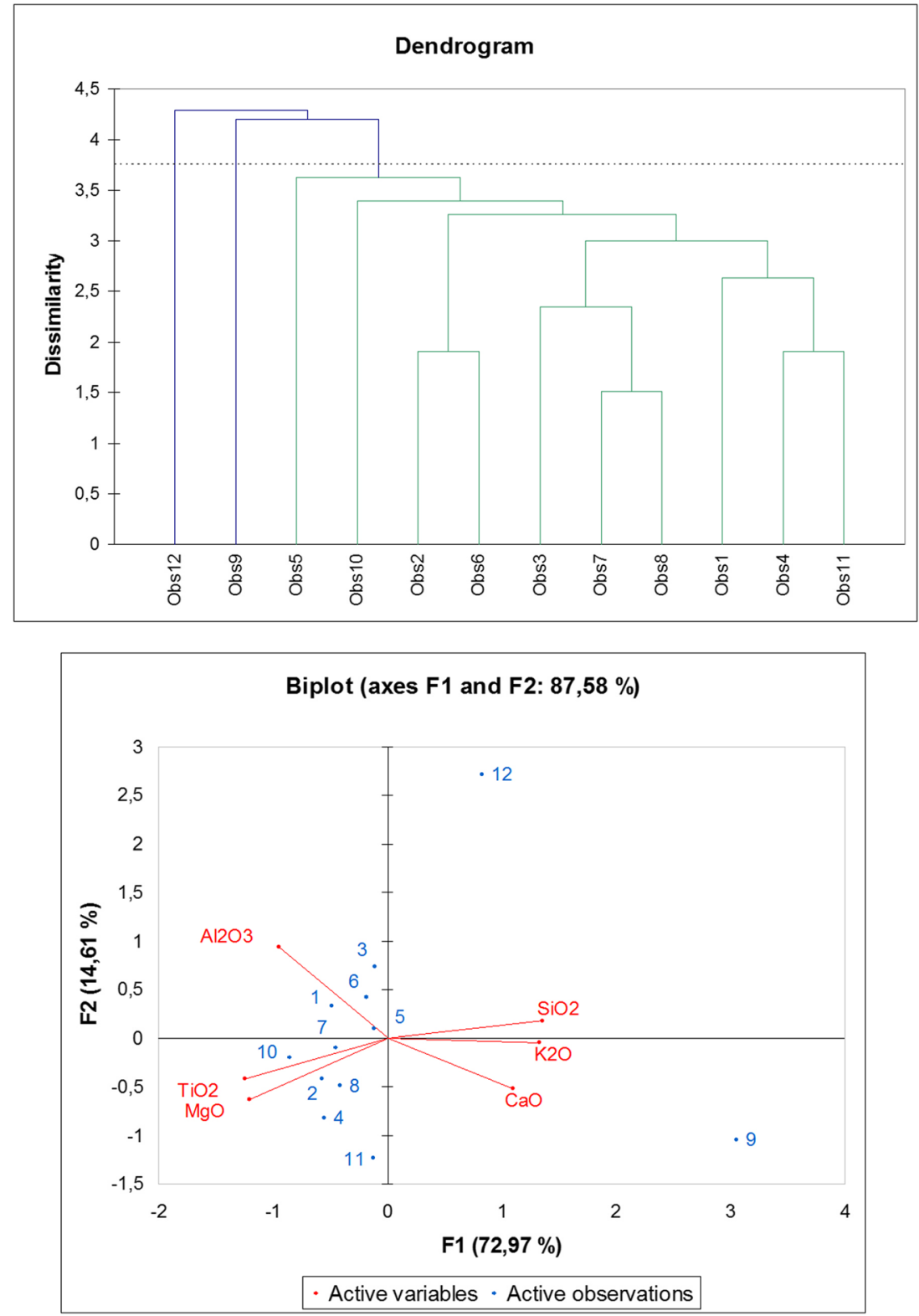

clustering-AHC) for the purpose of identification of groups of slag inclusions of different origin. The recommended procedure is dissimilarity type based on the Euclidean distance and agglomeration method of average linkage, although other linkage methods may produce similar effects. A dendrogram is obtained and individual groups are isolated by truncating the tree at the height where the agglomeration rate strongly decreases. A truncation correctness may be verified by comparing the obtained division into clusters with PC plots and thus by explaining the origins of individual groups on the basis of their relations to oxide correlation patterns. The identification model proposed here makes use of six oxides: $\mathrm{MgO}$, $\mathrm{Al}_{2} \mathrm{O}_{3}, \mathrm{SiO}_{2}, \mathrm{~K}_{2} \mathrm{O}, \mathrm{CaO}$ and $\mathrm{TiO}_{2}$. A classification of each inclusion group as smelting-derived slag inclusions or those derived from or contaminated with technical ceramic, clay or sand additives, or fuel ash is carried out on the basis of relationships offered in Table 2. Smelting-derived slag inclusions, which are of greatest interest here, will be located near the origin of the graph, as their chemical composition is formed by numerous parent materials (Charlton et al. 2012: p. 22832288, Figs. 1, 2, 3, 4, 5, 6; see also Charlton et al. 2013: 422, 425-426). This method of discrimination was used by Disser et al. (2014) in their work concerning construction iron in medieval French buildings. A difference was that only five oxides were included (without $\mathrm{TiO}_{2}$ ). Furthermore, a logratio data transformation was applied (Disser et al. 2014: p. 322-325; see also Disser et al. 2017).

Several characteristics can be proposed for the purpose of discrimination between the bloomery and the blast furnace process. In the approach discussed by Dillmann and 
Fig. 12 Gun barrel, MZM/468/ MT: identification of the iron smelting technology (sums of weighted contents* and weighted contents $* *$ of relevant oxides in slag inclusions). Background graphs (comparative data for individual artefacts — one point per artefact) - top: after Dillmann and L'Héritier 2007: p. 1819, Fig. 10; bottom: courtesy Dr. Maxime L'Héritier
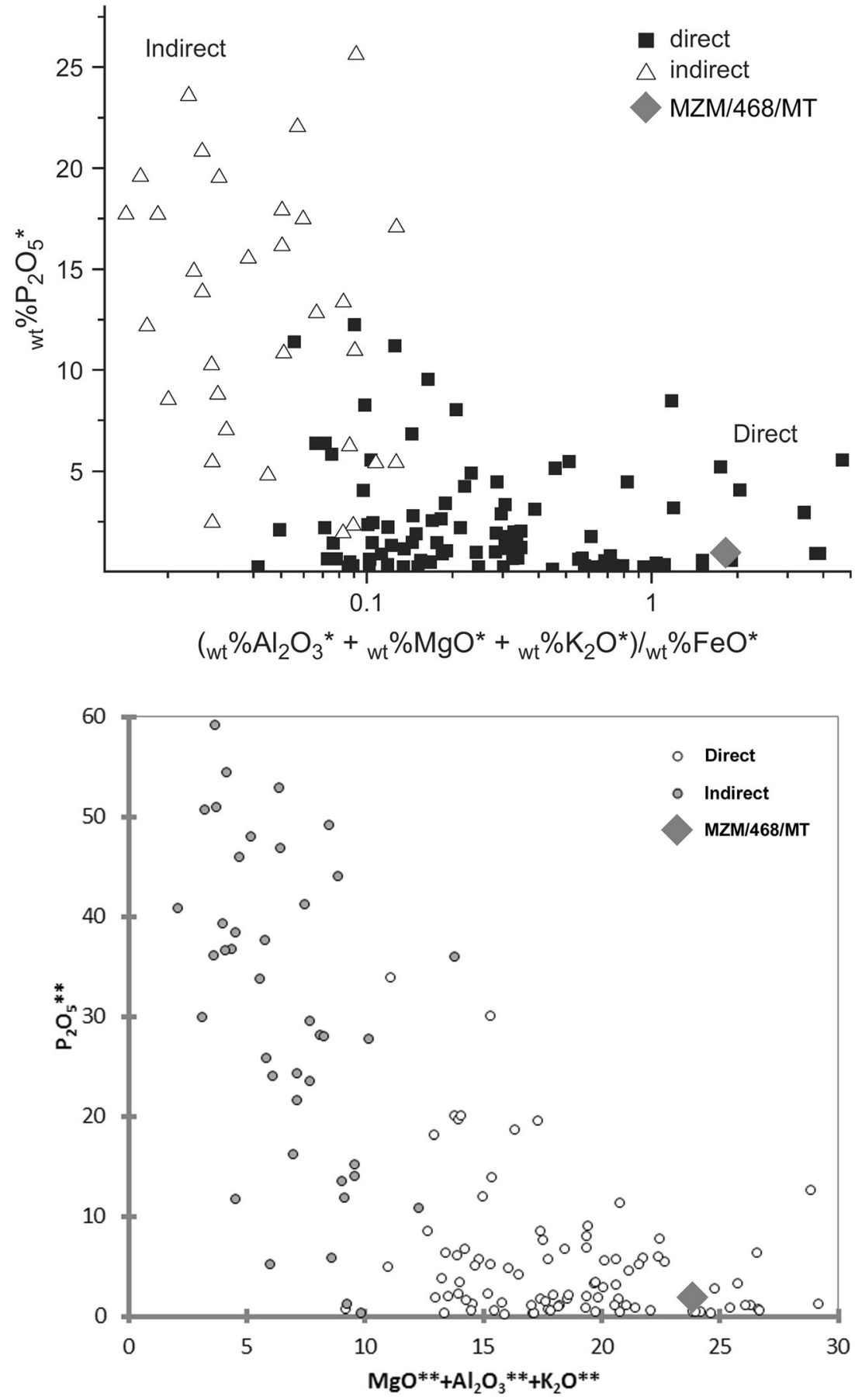

L'Héritier, wt $\%$ of $\mathrm{P}_{2} \mathrm{O}_{5}$ * are plotted on the $y$-axis of a biplot, while the $x$-axis is responsible for $\left(\mathrm{wt} \% \mathrm{Al}_{2} \mathrm{O}_{3} *+\right.$ $\left.\left.\mathrm{wt} \% \mathrm{MgO}^{*}+\mathrm{wt}^{2} \% \mathrm{~K}_{2} \mathrm{O}\right) / \mathrm{wt} \% \mathrm{FeO}^{*}\right)$. For most slag inclusions in artefacts made from indirect process iron, $y$ values are high while $x$ values are low. For direct process iron, the opposite is the case. Naturally, there will always be some overlapping zone or a "common domain" (Dillmann and L'Héritier 2007: p. 1816-1819, Tab. 4, Fig. 10; for other works where this method was used, see, e.g. Mamani-Calcina et al. 2017; Maia et al. 2015; L'Héritier et al. 2013; for earlier attempts at discriminating between both processes, see, e.g. Buchwald and Wivel 1998: p. 87-91, Tab. 4, Fig. 170).

As an alternative, one can also make use of oxides' weight percents which are divided by the Fe content in the slag inclusions (so-called weighted contents**). The biplot will display the following results (Eqs. 2 and 3):

$y$-axis : $\mathrm{wt}^{\circ} \mathrm{P}_{2} \mathrm{O}_{5}{ }^{* *}$, that is, 100

$$
\times\left(\mathrm{P}_{2} \mathrm{O}_{5}{ }^{*}\right) /\left(\left(\text { AllOxides }^{*}\right)-\mathrm{FeO}^{*}\right)
$$


Fig. 13 Gun barrel, MZM/468/ MT: identification of smeltingderived slag inclusions with the agglomerative hierarchical clustering (dissimilarity type,

Euclidean distance, Ward method agglomeration) (top) and the principal component analysis (bottom)
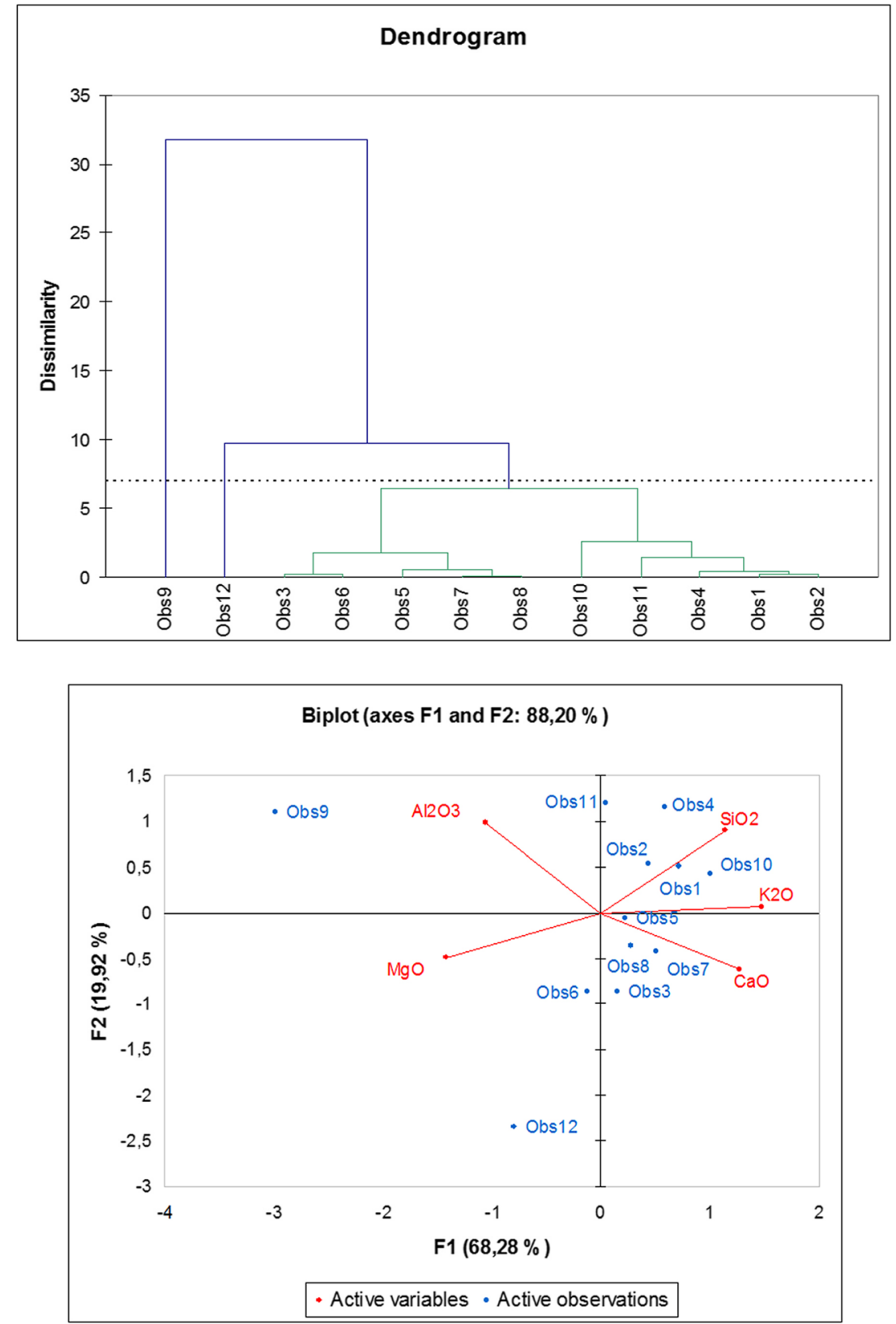

$\mathrm{x}$-axis : $\left(\mathrm{wt}^{2} \mathrm{Al}_{2} \mathrm{O}_{3}{ }^{* *}+\mathrm{wt} \% \mathrm{MgO}^{* *}+\mathrm{wt} \% \mathrm{~K}_{2} \mathrm{O}^{* *}\right)$, that is, $\left(100 \times\left(\mathrm{Al}_{2} \mathrm{O}_{3}{ }^{*}\right) /\left(\left(\right.\right.\right.$ AllOxides $\left.{ }^{*}\right)-$

$\left.\left.\mathrm{FeO}^{*}\right)\right)+\left(100 \times\left(\mathrm{MgO}^{*}\right) /\left(\left(\right.\right.\right.$ AllOxides $\left.\left.\left.{ }^{*}\right)-\mathrm{FeO}^{*}\right)\right)+\left(100 \times\left(\mathrm{K}_{2} \mathrm{O}^{*}\right) /\left(\left(\right.\right.\right.$ AllOxides $\left.\left.\left.{ }^{*}\right)-\mathrm{FeO}^{*}\right)\right)$

There will be the same principle of discrimination, that is, high $y$ values and low $x$ values low for the blast furnace (indirect) process and low $y$ values and high $x$ values for the bloomery (direct) process (Dr Maxime L'Héritier, personal communication, 9 June 2017; cf. Disser et al. 2014: p. 325).
In 2014, Disser et al. published results of their analyses of construction iron from Beauvais and Metz Cathedrals. They proposed yet another method of discrimination between both smelting processes, based on the method of logistic regression. With regard to the selection of smelting-derived slag inclusions, these researchers used the log-ratio approach at 
Table 2 Provenance of slag inclusions located at upper extremes of NRC pairs which demonstrate strong positive correlations (LC-localised concentration effect) (after Charlton et al. 2012: p. 2283, Tab. 2)

\begin{tabular}{|c|c|c|c|c|c|c|c|c|}
\hline & $\mathrm{MgO}$ & $\mathrm{Al}_{2} \mathrm{O}_{3}$ & $\mathrm{SiO}_{2}$ & $\mathrm{~K}_{2} \mathrm{O}$ & $\mathrm{CaO}$ & $\mathrm{TiO}_{2}$ & $\mathrm{SrO}$ & $\mathrm{BaO}$ \\
\hline $\mathrm{MgO}$ & LC/ash & & & ash & ash & & ash & \\
\hline $\mathrm{Al}_{2} \mathrm{O}_{3}$ & & LC/clay & clay & clay & & clay & & clay \\
\hline $\mathrm{SiO}_{2}$ & & clay & LC/flux & clay & & clay & & clay \\
\hline $\mathrm{K}_{2} \mathrm{O}$ & Ash & clay & clay & LC/ash/clay & ash & clay & ash & clay \\
\hline $\mathrm{CaO}$ & Ash & & & ash & LC/ash & & ash & \\
\hline $\mathrm{TiO}_{2}$ & & clay & clay & clay & & LC/clay & & clay \\
\hline $\mathrm{SrO}$ & Ash & & & ash & ash & & LC/ash & \\
\hline $\mathrm{BaO}$ & & clay & clay & clay & & clay & & LC/clay \\
\hline
\end{tabular}

the data transformation stage. For each slag inclusion, the following calculation was applied (Eq. 4):

$\left.X i_{N R C}=\log \left(\mathrm{Ei}_{\mathrm{NRC}}\right)-\mathrm{g}\left(\log \mathrm{E}_{\mathrm{NRC}}\right)\right)$

$i$ - individual slag inclusion

$X i_{N R C}$ - transformed value for each $\mathrm{NRC}\left(\mathrm{MgO}, \mathrm{Al}_{2} \mathrm{O}_{3}, \mathrm{SiO}_{2}, \mathrm{~K}_{2} \mathrm{O}, \mathrm{CaO}\right)$

$E i_{N R C}-\mathrm{NRC}$ amount in a given slag inclusion

$g\left(\log E_{N R C}\right)-$ geometrical mean of $\log$ of NRCs.

In order to deal with the problem of data distortion inferred by results below detection limits, such results were replaced with 0.25 . In the next stage, $X i_{\mathrm{NRC}}$ values were processed with a hierarchical cluster analysis (Euclidian distance, dissimilarity type, Ward linkage method). The obtained dendrogram was then truncated in order to isolate relevant clusters. The correctness of the truncation was verified by means of plotting the results of clustering on a PC score plot produced on the $X i_{\mathrm{NRC}}$ values and on bivariate graphs with NRC contents (Disser et al. 2014: p. 322-326, Figs. 6, 7, 8, 9, 10). In order to cope with data distortion caused by the matrix effect (which may lead to overrepresentation of $\mathrm{Fe}$ ), a subcompositional ratio for each oxide was calculated (Eq. 5):

$\%$ Oxide $^{* *}=\left(\%\right.$ Oxide $\left.{ }^{*} \times 100\right) /\left(100-\mathrm{FeO}^{*}\right)$.

On the basis of results of previous studies, differences in behaviour of certain oxides in both smelting processes were observed. $\mathrm{MgO}, \mathrm{Al}_{2} \mathrm{O}_{3}$ and $\mathrm{K}_{2} \mathrm{O}$ do not undergo reduction in the direct process and are strongly present in the slag and slag inclusions. These oxides are not reduced in the indirect process, either. On the other hand, they leave the smelting system in the liquid slag. As a consequence, slag inclusions which are formed in the refining stage contain a much lower amount of these oxides. In contrast to that, $\mathrm{P}$ oxides are partially reduced in cast iron and will be present in it as phosphorus eutectics. In the refining stage, slag inclusions with strong concentrations of $\mathrm{P}_{2} \mathrm{O}_{5}$ will be formed. Previous research did not consider $\mathrm{SiO}_{2}$ as a discriminating factor. However, analyses of the $\% \mathrm{SiO}_{2} * *$ distribution revealed differences between both processes. Such differences were also noted for $\mathrm{CaO}$ and $\mathrm{MnO}$, which is why these oxides were also taken into consideration. The problem of the overlapping zone between both processes can be dealt with by means of using a method to model the data as a function of the ironmaking process (Disser et al. 2014: p. 325).

For this purpose, the method of logistic regression was applied. Its rudiments can be explained using principles of the classical multivariate linear regression analysis:

- there is a quantitative variable $Y$ for which there is a number of possible explanatory variables $\left(X^{I}, X^{2} \ldots, X^{n}\right)$

- $\mathrm{Y}$ can be modelled as a linear combination of $X^{i}$, that is, $Y=\beta^{0}+\beta^{l} X^{l}+\beta^{2} X^{2} \ldots \beta^{n} X^{n}$

The $\left(\beta^{l}, \beta^{2}, \ldots \beta^{n}\right)$ coefficients are related to the relative contribution of each variable to the prediction of the outcome $Y$. For assemblages of observed $\left(Y_{i}\right)$ and corresponding $\left(X_{i}^{1}, X_{i}^{2}\right.$ $\left.\ldots X_{i}^{n}\right)$ variables, it is possible to estimate the $\left(\beta^{l}, \beta^{2}, \ldots \beta^{n}\right)$ with the use of maximum likelihood. Then, the estimated values are used for predictions of new outcomes $\left(Y_{j}\right)$ from relevant new assemblages of variables $\left(X_{j}^{1}, X_{j}^{2} \ldots X_{j}^{n}\right)$. When the $Y$ outcome is binary (the process to be identified will be either direct or indirect), it is possible to apply multivariate logistic regression instead of linear regression. In this case, the linear combination of variables $\left(X_{j}^{1}, X_{j}^{2} \ldots X_{j}^{n}\right)$ is applied to model the Logit $(p)$, in which $p$ is the probability of $Y=1$ and $\operatorname{Logit}(p)=\log (p / 1-p)$ represents a continuous variable varying between $-\infty$ and $+\infty$. Therefore, the logistic regression model can be expressed as $\operatorname{Logit}(p)=\beta^{0}+\beta^{l} X^{l}+$ $\beta^{2} X^{2} \ldots \beta^{n} X^{n}$. The $\left(\beta^{1}, \beta^{2}, \ldots \beta^{n}\right)$ coefficients are estimated by maximum likelihood with the use of assemblages $\left(X_{i}^{1}, X_{i}^{2}\right.$ $\ldots X_{i}^{n}$ ) for which the value of $Y$ is known and is 0 or 1 . Then, new assemblages of variables $\left(X_{j}^{1}, X_{j}^{2} \ldots X_{i}^{n}\right)$ are evaluated and the probability $\mathrm{p}$ is predicted with the use of $\operatorname{Logit}(p)=\beta^{0}+\beta^{l} X^{1}+\beta^{2} X^{2} \ldots \beta^{n} X^{n}$ (Disser et al. 2014: $\mathrm{p}$. 325-326). 
For the purpose of discrimination between the direct and the indirect process, the $Y$ variable is constructed in such a manner that $Y=0$ for the direct process, and $Y=1$ for the indirect process. The final shape of the equation is the following (Eq. 6):

$$
\begin{aligned}
& \operatorname{Logit}(\mathrm{p})= \beta^{0}+\beta^{M g}\left[\% \mathrm{MgO}^{* *}\right]+\beta^{\mathrm{Al}}\left[\% \mathrm{Al}_{2} \mathrm{O}_{3}{ }^{* *}\right] \\
&+\beta^{S i}\left[\% \mathrm{SiO}_{2}{ }^{* *}\right]+\beta^{P}\left[\% \mathrm{P}_{2} \mathrm{O}_{5}{ }^{* *}\right]+\beta^{K}\left[\% \mathrm{~K}_{2} \mathrm{O}^{* *}\right] \\
&+\beta^{C a}\left[\% \mathrm{CaO}^{* *}\right]+\beta^{M n}\left[\% \mathrm{MnO}^{* *}\right] .
\end{aligned}
$$

The eight coefficients of the model $\left(\beta^{0}+\beta^{M g}+\beta^{A l}+\beta^{S i}+\right.$ $\beta^{P}+\beta^{K}+\beta^{C a}+\beta^{M n}$ ) were calculated on the basis of a reference set of 138 samples for which the smelting process was known. The maximum likelihood estimation was done with a numerical iterative approach based on the Bayesian optimisation algorithm. One can also calculate corresponding probabilities for the indirect $(p)$ or the direct $(1-p)$ process. The process which has the highest predicted probability corresponds to the known process, with $p>0.5$ for all samples which come from the indirect process and $p<0.5$ from samples of iron manufactured in the direct process. Using the logit parameters (Table 3), it is possible to calculate probabilities for any other sample (Disser et al. 2014: p. 326-328, Tab. 5).

Using this approach, 16 out of 18 samples from Beauvais Cathedral were classified as coming from the direct process, while two samples were undetermined. For Metz Cathedral, 11 out of 43 samples were classified to the direct process, 2 were undetermined and the remaining ones were classified as related to the indirect process. The Logit $(p)$ values were strongly positive (between 1.95 and 8.30) for the indirect process and strongly negative for the direct process (between -18.26 and -2.32 ) (Disser et al. 2014: p. 328-329, Tabs. 7-8, Fig. 13).

With several methods of identification of the ironmaking process being available, it was decided to verify whether the discussed barrel was in fact manufactured from bloomery metal. Data was processed in Excel and statistical calculations were done in Xlstat. It must be of course said that this verification is burdened with a considerable risk. As mentioned

Table 3 Parameters of the logistic regression estimated with the reference set of 138 samples (after Disser et al. 2014: p. 328, Tab. 5)

\begin{tabular}{llcl}
\hline Oxide** & Parameter & Value & Std. error \\
\hline Intercept & $B^{0}$ & 5.22 & 3.320 \\
$\mathrm{MgO}$ & $\beta^{M g}$ & 0.13 & 0.35 \\
$\mathrm{Al}_{2} \mathrm{O}_{3}$ & $\beta^{4 l}$ & -0.95 & 0.25 \\
$\mathrm{SiO}_{2}$ & $\beta^{S i}$ & 0.007 & 0.043 \\
$\mathrm{P}_{2} \mathrm{O}_{5}$ & $\beta^{P}$ & 0.16 & 0.065 \\
$\mathrm{~K}_{2} \mathrm{O}$ & $\beta^{K}$ & -0.84 & 0.44 \\
$\mathrm{CaO}$ & $\beta^{C a}$ & 0.088 & 0.058 \\
$\mathrm{MnO}$ & $\beta^{M n}$ & 0.018 & 0.091 \\
\hline
\end{tabular}


Table 5 Gun barrel, MZM/468/MT: subcompositional ratios and their -log values of selected oxides in slag inclusions

\begin{tabular}{|c|c|c|c|c|c|c|c|c|c|c|c|c|c|c|c|c|c|c|}
\hline \multicolumn{7}{|c|}{0 values replaced with the lowest value for a given oxide } & \multicolumn{6}{|c|}{ Subcompositional ratios } & \multicolumn{6}{|c|}{ Subcompositional ratios' - log values } \\
\hline & $\mathrm{MgO}$ & $\mathrm{Al}_{2} \mathrm{O}_{3}$ & $\mathrm{SiO}_{2}$ & $\mathrm{~K}_{2} \mathrm{O}$ & $\mathrm{CaO}$ & $\mathrm{TiO}_{2}$ & $\mathrm{MgO}$ & $\mathrm{Al}_{2} \mathrm{O}_{3}$ & $\mathrm{SiO}_{2}$ & $\mathrm{~K}_{2} \mathrm{O}$ & $\mathrm{CaO}$ & $\mathrm{TiO}_{2}$ & $\mathrm{MgO}$ & $\mathrm{Al}_{2} \mathrm{O}_{3}$ & $\mathrm{SiO}_{2}$ & $\mathrm{~K}_{2} \mathrm{O}$ & $\mathrm{CaO}$ & $\mathrm{TiO}_{2}$ \\
\hline SI1 & 0.72 & 1.12 & 7.54 & 0.61 & 0.90 & 0.10 & 0.065 & 0.102 & 0.686 & 0.056 & 0.082 & 0.009 & 1.185 & 0.992 & 0.164 & 1.255 & 1.086 & 2.041 \\
\hline SI2 & 2.50 & 3.99 & 23.49 & 1.87 & 2.84 & 0.10 & 0.072 & 0.115 & 0.675 & 0.054 & 0.082 & 0.003 & 1.144 & 0.941 & 0.170 & 1.270 & 1.089 & 2.541 \\
\hline SI3 & 2.62 & 3.31 & 16.84 & 1.68 & 2.78 & 0.36 & 0.095 & 0.120 & 0.610 & 0.061 & 0.101 & 0.013 & 1.022 & 0.921 & 0.214 & 1.216 & 0.997 & 1.885 \\
\hline SI4 & 1.31 & 2.73 & 15.40 & 1.39 & 1.67 & 0.10 & 0.058 & 0.121 & 0.681 & 0.062 & 0.074 & 0.004 & 1.238 & 0.918 & 0.167 & 1.211 & 1.131 & 2.354 \\
\hline SI5 & 2.32 & 3.85 & 18.93 & 1.50 & 2.93 & 0.33 & 0.078 & 0.129 & 0.634 & 0.050 & 0.098 & 0.011 & 1.110 & 0.890 & 0.198 & 1.298 & 1.008 & 1.952 \\
\hline SI6 & 3.37 & 3.42 & 17.78 & 1.53 & 2.69 & 0.12 & 0.116 & 0.118 & 0.615 & 0.053 & 0.093 & 0.004 & 0.934 & 0.927 & 0.211 & 1.276 & 1.032 & 2.393 \\
\hline SI7 & 2.92 & 6.10 & 28.16 & 2.71 & 5.40 & 0.32 & 0.064 & 0.134 & 0.617 & 0.059 & 0.118 & 0.007 & 1.194 & 0.873 & 0.209 & 1.226 & 0.927 & 2.158 \\
\hline SI8 & 3.19 & 6.43 & 27.53 & 2.62 & 5.07 & 0.18 & 0.071 & 0.143 & 0.612 & 0.058 & 0.113 & 0.004 & 1.149 & 0.845 & 0.214 & 1.235 & 0.949 & 2.391 \\
\hline SI9 & 1.23 & 1.21 & 2.37 & 0.08 & 0.22 & 0.37 & 0.224 & 0.220 & 0.433 & 0.015 & 0.041 & 0.067 & 0.650 & 0.657 & 0.364 & 1.813 & 1.389 & 1.175 \\
\hline SI10 & 1.41 & 3.16 & 19.51 & 1.40 & 3.11 & 0.10 & 0.049 & 0.110 & 0.680 & 0.049 & 0.108 & 0.003 & 1.308 & 0.959 & 0.167 & 1.312 & 0.965 & 2.458 \\
\hline SI11 & 1.18 & 2.42 & 10.83 & 1.02 & 1.13 & 0.10 & 0.071 & 0.145 & 0.649 & 0.061 & 0.068 & 0.006 & 1.151 & 0.839 & 0.188 & 1.212 & 1.168 & 2.222 \\
\hline SI12 & 1.79 & 0.77 & 4.41 & 0.31 & 0.73 & 0.23 & 0.217 & 0.094 & 0.534 & 0.038 & 0.088 & 0.028 & 0.663 & 1.027 & 0.272 & 1.420 & 1.054 & 1.548 \\
\hline
\end{tabular}

above, the part of the barrel from which the sample was taken may have been re-forged. Due to financial and technical constraints, it was not possible to meet the requirement of analysing at least 40 slag inclusions, which can obviously render the results not fully representative. In the first stage, results of both series of analyses were converted to oxides and normalised to $100 \%$. Then, ratios of selected oxides and their determination coefficients $R^{2}$ were calculated (Table 4 ).

As it can be seen, the determination coefficient is below the required level of 0.7 in three cases. After the elimination of SI6, SI9 and SI12, the $R^{2}$ would be $>0.7$ for all ratios. Before a final decision, the method of verification proposed by Charlton et al. (2012) was applied. For this purpose, subcompositional ratios and their $-\log$ values were calculated (Table 5 ).

A correlation-type PCA was run on the obtained -log values. Next, raw PC scores were processed with the AHC (dissimilarity type, Euclidean distance, weighted pair-group average agglomeration). Three groups of inclusions were isolated. On the basis on their position on the PCA biplot, group 1 (which also included SI6) can be identified as smeltingderived slag, group 2 (SI9) derives from or is contaminated with ash and clay, while the origin of group 3 (SI12) cannot be easily determined (Fig. 11). Although the determination coefficient $R^{2}$ was not $>0.7$ in the case of all oxide ratios for the remaining slag inclusions (it was 0.57 for $\mathrm{MgO} / \mathrm{Al}_{2} \mathrm{O}_{3}, 0.60$ for $\mathrm{K}_{2} \mathrm{O} / \mathrm{MgO}$ and 0.57 for $\mathrm{SiO}_{2} / \mathrm{MgO}$ ), it was anyway decided to keep SI6 in the dataset.

Weighted contents* of oxides in smelting-derived slag inclusions were calculated according to Eq. 1. Then, weighted contents** were calculated in line with Eqs. 2 and 3 (Table 6). Eventually, results of both calculations were plotted on a biplot (Fig. 12). The results in both cases strongly suggest that the gun barrel in question was manufactured with the use of bloomery iron.
A verification of the result with the logistic regression method was carried out (Table 7). The proposed Eq. 4 for the log-ratio transformation was not implemented, as logs of oxide values below 1 would be negative. This could cause problems with the geometrical mean. Instead, the log-ratio transformation as discussed in Charlton et al. (2012) was applied (Eq. 7):

$\mathrm{x}_{\mathrm{ij}} \leftarrow \log \left[\mathrm{x}_{\mathrm{ij}} / \mathrm{g}\left(\mathrm{X}_{\mathrm{i}}\right)\right]$

$\mathrm{x}_{\mathrm{ij}}-\mathrm{j}^{\text {th }}$ variable in the $\mathrm{i}^{\text {th }}$ case

$g\left(X_{i}\right)$ - geometrical mean of all variables in the $\mathrm{i}^{\text {th }}$ composition

The next step was the PCA of the log values, followed by the AHC (Ward method) on raw PC scores. The results are similar with regard to the identification of smelting-derived slag inclusions (group 1 also in this case, with the same SIs, see Fig. 13) as in the previous method.

In the next stage, the subcompositional ratio for each oxide was calculated (Table 8). As Eq. 5 produced results which hardly differed from the weighted contents*, the subcompositional ratios were calculated for each oxide in all inclusions together (Eq. 8):

$\%$ Oxide $^{* *}=\left(\right.$ sum of $\%$ oxide $^{*}$ in all inclusions $\left.\times 100\right) /$

(100-Sum of $\mathrm{FeO}^{*}$ in all inclusions).

The obtained results were used for Eq. 6, with $\beta$ parameters from Table 4. In result, the $\operatorname{Logit}(p)=-7.697$ was obtained. In order to verify it, the $p$ value was calculated $\left(p=e^{\operatorname{logit}(p)} /(1+\right.$ $\left(e^{\operatorname{logit}(p)}\right) ; e$-exponential function). The $p$ value $=0.000454$ was obtained, and the $\operatorname{Logit}(p)$ was calculated again. Instead of the formula proposed by Disser et al. (2014), the natural logarithm was applied: $\operatorname{Logit}(p)=\ln (p / 1-p)$. As a result, the 


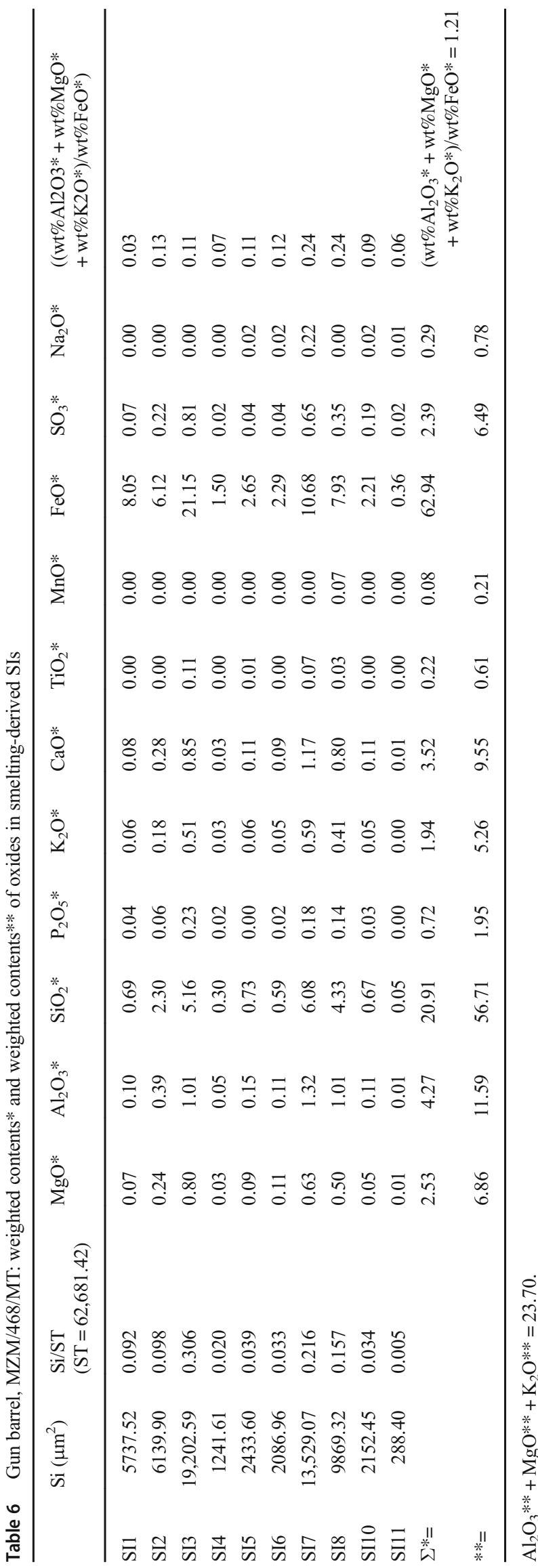

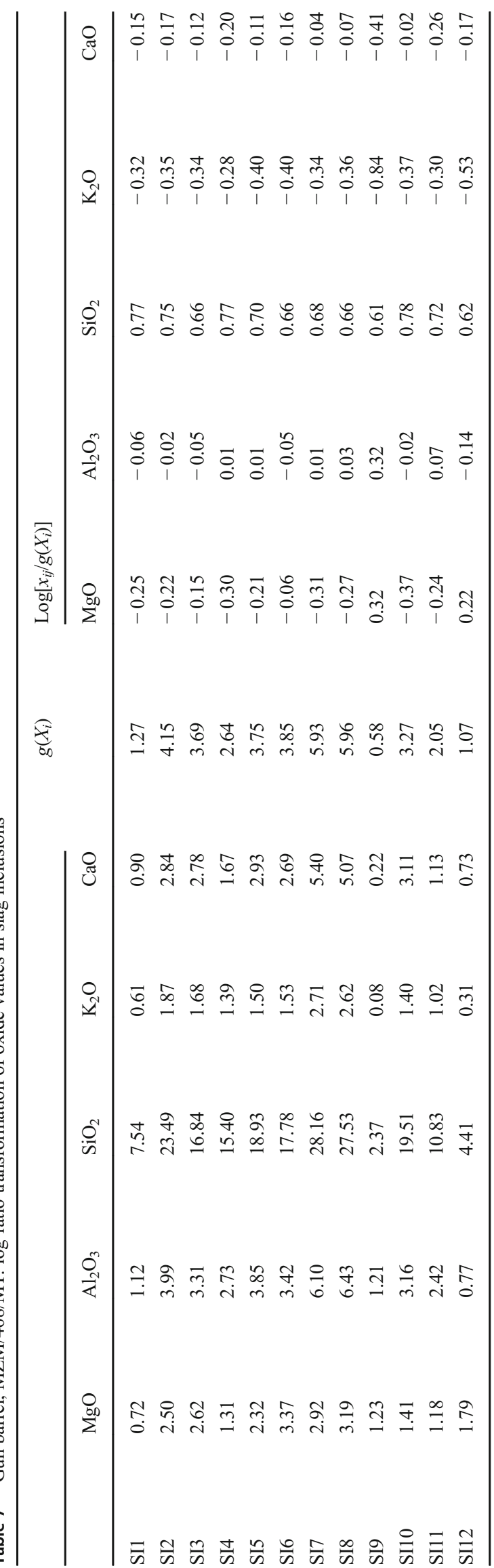


Table 8 Gun barrel, MZM/468/MT: subcompositional ratios of oxides in smelting-derived SIs

\begin{tabular}{llllllll} 
& $\mathrm{MgO}^{* *}$ & $\mathrm{Al}_{2} \mathrm{O}_{3} * *$ & $\mathrm{SiO}_{2}^{* *}$ & $\mathrm{P}_{2} \mathrm{O}_{5}^{* *}$ & $\mathrm{~K}_{2} \mathrm{O} * *$ & $\mathrm{CaO}^{* * *}$ & $\mathrm{MnO}^{* * *}$ \\
\hline $\begin{array}{l}\mathrm{SI} \\
\text { total }\end{array}$ & & 11.82 & 56.43 & 1.94 & 5.23 & 9.51 & 0.21 \\
\hline
\end{tabular}

value of -7.696 was obtained, which proves the correctness of the entire operation. On the basis of the aforementioned Logit $(p)$ values for the indirect and the direct process being between 1.95 and 8.30 , and between -18.26 and -2.32 , respectively, it was confirmed that the metal in the discussed gun was obtained in the direct process.

\section{Conclusions}

It can be assumed that the discussed gun barrel was originally part of a hand-held weapon, possibly a heavy hackbut of a late 15 th-early 16 th c. chronology. Such firearms were fairly popular in this period and may have long remained in use. For unknown reasons (perhaps after a damage?) and in unspecified point of time, it was converted into some sort of a light cannon, intended to be mounted on a carriage. On the other hand, it is difficult to propose a direct analogy to the gun in its present shape. On the basis of analysis of the slag inclusions with the use of different methods, it can be proposed that the barrel was manufactured from low carbon soft steel coming from the bloomery (direct) smelting process. Results of analyses of other gun barrels suggest that the use of such metal for gun barrels of such a type was rather typical in the period in question. For the sake of comparison of the technology of manufacture of the discussed gun with other technological solutions used in medieval and early modern ironworking, the reader is sent to some most important works on this issue (e.g. Pleiner 2000, 2006; Buchwald 2005, 2008; Williams 2003, 2012; Tylecote 1976; Tylecote and Gilmour 1986. It must be remembered that care is needed here, as the sample was taken from the part of the gun which in all probability underwent re-forging and the number of analysed inclusions was rather low. It can be hoped that new research, perhaps with the use of improved analytical methods, will reveal new facts on the technology of manufacture of late medieval and modern period firearms. Furthermore, it could be recommended to re-examine already analysed examples of firearms in order to verify previous research results with the use of methods offered by multivariate statistics.

Acknowledgements The authors are obliged to Dr. Maxime L'Héritier for his kind consultation and supply of comparative data. Thanks must also go to Dr. Eng. Janusz Stępiński and Prof. Marcin Biborski for their help during the technological analyses. Furthermore, the authors are indebted to two anonymous reviewers, whose comments significantly improved this paper.

Open Access This article is distributed under the terms of the Creative Commons Attribution 4.0 International License (http:// creativecommons.org/licenses/by/4.0/), which permits unrestricted use, distribution, and reproduction in any medium, provided you give appropriate credit to the original author(s) and the source, provide a link to the Creative Commons license, and indicate if changes were made.

\section{References}

\section{Archival Sources}

Castle Museum in Malbork, Arms and Armour Collection - Cannon Barrel, MZM/468/MT (inventory card)

Zeugbuch (c. 1502) Zeugbuch Kaiser Maximilians I. Innsbruck. Bayerische Staatsbibliothek München, Cod. Icon. 222

\section{Literature}

Blakelock E, Martinón-Torres M, Veldhuijzen HA, Young T (2009) Slag inclusions in iron objects and the quest for provenance: an experiment and a case study. J Archaeol Sci 36:1245-1757. https://doi.org/ 10.1016/j.jas.2009.03.032

Buchwald VF (2005) Iron and steel in ancient times. Historisk-filosofiske Skrifter 29. The Royal Danish Academy of Sciences and Letters, Copenhagen

Buchwald VF (2008) Iron, steel and cast iron before Bessemer. Historiskfilosofiske Skrifter 32. The Royal Danish Academy of Sciences and Letters, Copenhagen

Buchwald VF, Wivel H (1998) Slag analysis as a method for the characterization and Provenancing of ancient Iron objects. Mater Charact 40:73-96. https://doi.org/10.1016/S1044-5803(97)00105-8

Charlton MF, Blakelock E, Martinón-Torres M, Young T (2012) Investigating the production provenance of iron artifacts with multivariate methods. J Archaeol Sci 39:2280-2293. https://doi.org/10. 1016/j.jas.2012.02.037

Charlton MF, Crew P, Rehren T, Shennan SJ (2013) Measuring variation in iron smelting slags: an empirical evaluation of groupidentification procedures. In: Humphris J, Rehren T (eds). The World of Iron, London, pp 421-430

Dillmann PH, L'Héritier M (2007) Slag inclusion analyses for studying ferrous alloys employed in French medieval buildings: supply of materials and diffusion of smelting processes. J Archaeol Sci 34: 1810-1823. https://doi.org/10.1016/j.jas.2006.12.022

Disser A, Dillmann PH, Bourgain C, L'Héritier M, Vega E, Bauvais S, Leroy M (2014) Iron reinforcements in Beauvais and Metz cathedrals: from bloomery or finery? The use of logistic regression for differentiating smelting processes. J Archaeol Sci 42:315-333. https://doi.org/10.1016/j.jas.2013.10.034

Disser A, Dillmann PH, Leroy M, L'Héritier M, Bauvais S, Fluzin P (2017) Iron supply for the building of Metz cathedral: new methodological development for provenance studies. Archaeometry 59: 493-510. https://doi.org/10.1111/arcm.12265

Engel B (1900-1902) Zwei mittelalterliche Büchsen. Z Hist Waffenkunde 2:301-302

Figel' D, Hložěk M, Hošek J, Schenk Z, Žákovský P (2010) Interdisciplinárni analýza roztržené železné hákovnice $\mathrm{z}$ hradu Helfštýn (an interdisciplinary analysis of a burst iron hackbut from 
the castle of Helfštýn). Castellologia Bohem 12:477-488 http://hdl. handle.net/11104/0203790

Fondevilla Silva P, Sánchez Baena JJ (2012) Una nueva pieza de artilleria de galeras del siglo XVI: el esmeril bastardo "Matacapitanes". Gladius 32:185-210. https://doi.org/10.3989/gladius.2012.0009

Forrer R (1905) Meine gotischen Handfeuerrohre. In Koetschau E (ed) Beiträge zur Geschichte der Handfeuerwaffen. Festschrift zum 80. Geburtstag von Moritz Thierbach, Dresden, pp. 23-31

Głosek M (1990) Broń palna (Firearms). In: Nadolski A (ed) Uzbrojenie w Polsce średniowiecznej 1350-1450 (Arms and armour in medieval Poland, 1350-1450). Instytut Historii Kultury Materialnej Polskiej Akademii Nauk, Łódź, pp 155-164

Johanssen O (1918) Die Anwendung des Gusseisens im Geschutzwesen des Mittelalters und der Renaissance. Z Hist Waffenkunde 8:1-20

Klimek L, Stępiński J, Strzyż P, Żabiński G (2013) Late medieval wrought iron firearms from the Museum in Biecz. Fasciculi Archaeologiae Historicae 26:83-98 http://rcin.org.pl/dlibra/ doccontent?id=50105

L'Héritier M, Dillmann PH, Aumard S, Fluzin PH (2013) Iron? Which iron? Methodologies for metallographic and slag inclusion studies applied to ferrous reinforcements from Auxerre cathedral. In: Humphris J, Rehren T (eds) The world of Iron. Archetype Publications, London, pp 409-420

Lazar T (2017) The Slovenian lands as the armed frontier of the holy roman empire. Fasciculi Archaeologiae Historicae 30:59-72. https:// doi.org/10.23858/FAH30.2017.006

Maia RR, Dias MS, de Farias Azevedo CR, Landgraf FJG (2015) Archaeometry of ferrous artefacts from Luso-Brazilian archaeological sites near Ipanema River, Brazil, REM. Revista Escola de Minas, Ouro Preto 68.2:187-193. https://doi.org/10.1590/037044672015680151

Makovskaya LK (1992) Ručnoe ognestelnoe oruže russkoy armii konca XIV-XVIII v. Voennoe Izdatelstvo, Moskva

Malčenko O (2011) Museum artilleriae ucrainicae saeculi XV-XVIII pars prima. Nacionalna Akademia Nauk Ukrainy, Kiovia

Mamani-Calcina EA, Landgraf FJG, de Farias Azevedo CR (2017) Investigating the provenance of Iron artifacts of the Royal Iron Factory of São João de Ipanema by hierarchical cluster analysis of EDS microanalyses of slag inclusions, Mater Res 20.1: 119-129 doi:https://doi.org/10.1590/1980-5373-MR-2016-0444

McLachlan S (2010) Medieval handgonnes. The first black powder infantry weapons. Osprey Weapon 3, Oxford

Mielczarek M (1998) Recczna broń palna (Hand-held firearms). In: Nowakowski A (ed) Uzbrojenie w Polsce średniowiecznej 1450
1500 (Arms and armour in medieval Poland, 1450-1500). Uniwersytet Mikołaja Kopernika, Toruń, pp 60-64

Oakeshott E (2000) European weapons and armour. From the renaissance to the industrial revolution. 2nd ed. Boydell Press, Woodbridge

Pleiner R (2000) Iron in archaeology: the European bloomery smelters. Archeologický ústav AV ČR, Praha

Pleiner R (2006) Iron in archaeology: early European blacksmiths. Archeologický ústav AV ČR, Praha

Schedelmann H (1939) Untersuchung einer schmiedeisernen Steinbüchse aus dem 15. Jahrhundert. Z Hist Waffen Kostümkunde 41(Neue Folge 8):81-82

Smith RD (2000) The technology of wrought-iron artillery. R Armouries Yearb 5:68-80

Smith RD, Brown RR (1989) Bombards Mons Meg and Her Sisters. Royal Armouries Monograph 1, London

Smith RD, DeVries K (2005) The artillery of the dukes of burgundy, 1363-147. Boydell Press, Woodbridge

Strzyż P (2011) Broń palna w Polsce średniowiecznej. Studium archeologiczne (Firearms in medieval Poland. An archaeological study). Instytut Archeologii i Etnologii PAN, Łódź

Strzyż P (2014a) Broń palna w Europie Środkowej w XIV-XV w. (Firearms in Central Europe in the 14th-15th c.). Instytut Archeologii i Etnologii PAN, Łódź

Strzyż P (2014b) Nieznana lufa działa z Muzeum Historycznego w Sanoku (An unknown cannon barrel from the historical Museum in Sanok). Rocz Sanocki 11:63-71

Szymczak J (2004) Początki broni palnej w Polsce 1383-1533 (Beginnings of firearms in Poland 1383-1533). Uniwersytet Łódzki, Łódź

Thierbach M (1897-1899) Über die erste Entwickelung der Handfeuerwaffen. Z Hist Waffenkunde 1.6:129-132

Tylecote RF (1976) A history of metallurgy. Metals Society, London

Tylecote RF, Gilmour BJJ (1986) The metallography of early ferrous edge tools and edged weapons. British archaeological reports. British Series 155. Oxford

Williams AR (2003) The knight and the blast furnace. A history of the metallurgy of armour in the middle ages \& the early modern period. Brill, Leiden

Williams AR (2012) The sword and the crucible. A history of the metallurgy of European swords up to the 16th century. Brill, LeidenBoston

Żabiński G, Biborski M, Biborski M, Stępiński J, Miśta EA (2018) A late medieval or early modern ferrous hackbut barrel from the collection of the Castle Museum in Malbork, Acta Militaria Mediaevalia 14 (forthcoming) 